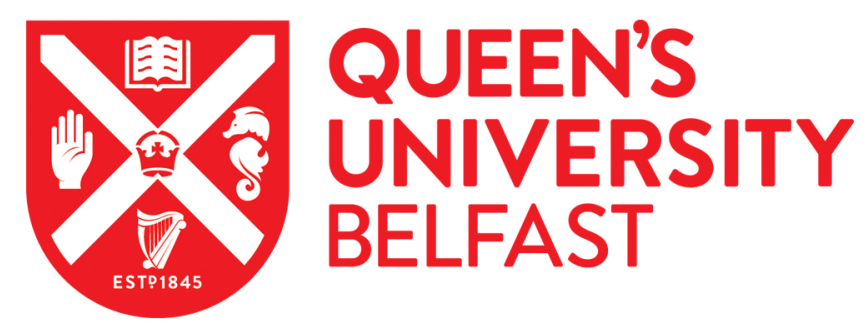

\title{
Why Do We Do What We Do? Comparing Legal Methods in Five Law Schools Through Survey Evidence
}

Mac Sithigh, D., \& Siems, M. (2017). Why Do We Do What We Do? Comparing Legal Methods in Five Law Schools Through Survey Evidence. In Rethinking Legal Scholarship: A Transatlantic Dialogue (pp. 31-83). Cambridge University Press . https://doi.org/10.1017/9781316442906.002

Published in:

Rethinking Legal Scholarship: A Transatlantic Dialogue

Document Version:

Peer reviewed version

Queen's University Belfast - Research Portal:

Link to publication record in Queen's University Belfast Research Portal

Publisher rights

Copyright 2017 Cambridge University Press

This work is made available online in accordance with the publisher's policies. Please refer to any applicable terms of use of the publisher.

\section{General rights}

Copyright for the publications made accessible via the Queen's University Belfast Research Portal is retained by the author(s) and / or other copyright owners and it is a condition of accessing these publications that users recognise and abide by the legal requirements associated with these rights.

Take down policy

The Research Portal is Queen's institutional repository that provides access to Queen's research output. Every effort has been made to ensure that content in the Research Portal does not infringe any person's rights, or applicable UK laws. If you discover content in the Research Portal that you believe breaches copyright or violates any law, please contact openaccess@qub.ac.uk. 


\title{
Why Do We Do What We Do? \\ Comparing Legal Methods in Five Law Schools \\ Through Survey Evidence
}

\author{
Mathias M. Siems and \\ Daithí Mac Síthigh
}

\begin{abstract}
Final version to be published, in Rob van Gestel, Hans Micklitz and Edward L. Rubin (eds.), Rethinking Legal Scholarship: A Transatlantic Interchange, New York: Cambridge University Press, 2015 (or 2016)
\end{abstract}

\begin{abstract}
For the purpose of this paper we conducted an empirical survey of academic staff at two German law schools (Heinrich-Heine University Düsseldorf; Bucerius Law School), two UK ones (University of East Anglia; University of Edinburgh) and one Irish one (Trinity College, Dublin). We asked the legal scholars to indicate to what extent they identify with legal research as part of humanities, as part of social sciences, and as akin to the analysis of law in legal practice. In this paper we present and discuss our results, using tools of both classical and compositional statistics. We also relate our data to contextual information about these legal scholars (e.g., training, career stage) as well as institutional and country differences. Our main general finding is that scholars of the German law schools have a relatively strong preference for practical legal research and scholars of the UK and Irish law schools a relatively strong preference for law as humanities. Some of our specific findings are that international legal scholars tend to be closer to the social sciences and that younger scholars and private lawyers tend to be closer to practical legal research. We also observe some signs of convergence since, across the five law schools, scholars told us that they tend to use practical legal research methods less often, and social sciences methods more often, than ten years ago.
\end{abstract}

Keywords: legal methods, interdisciplinarity, doctrinal legal research, legal practice, humanities, social sciences, academic disciplines, law schools 


\section{Table of contents:}

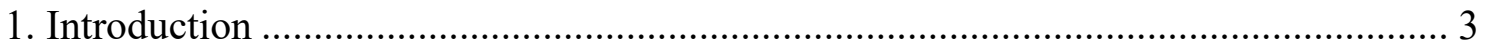

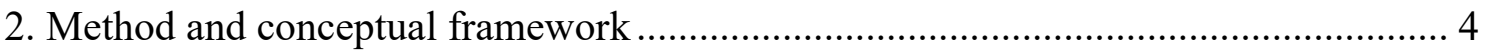

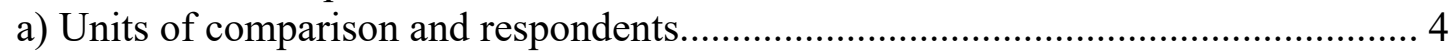

b) Procedure of data collection and survey method ................................................ 5

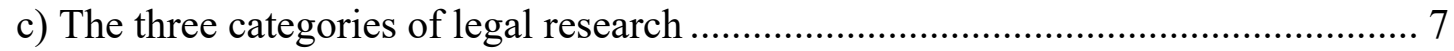

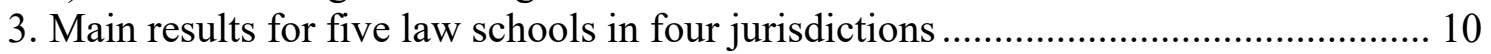

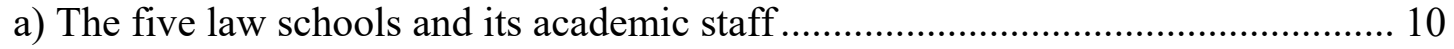

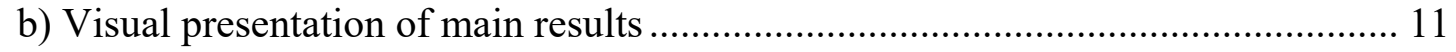

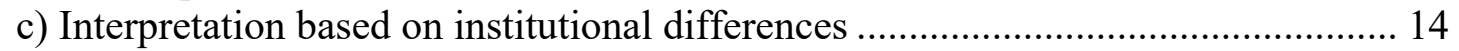

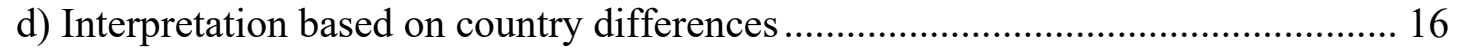

(i) The role of legal families ....................................................................................... 16

(ii) Further factors, in particular higher education ............................................. 17

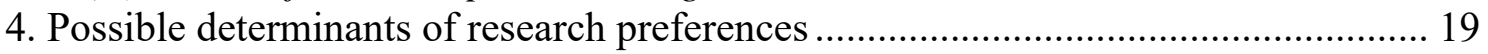

a) Analysis of possible general determinants ....................................................... 20

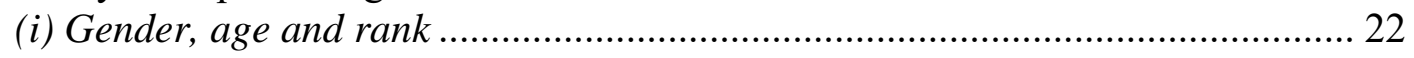

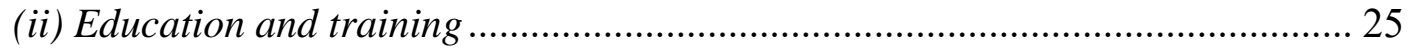

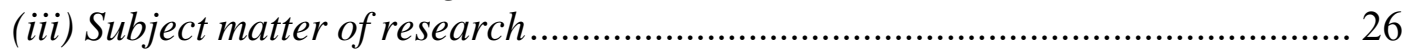

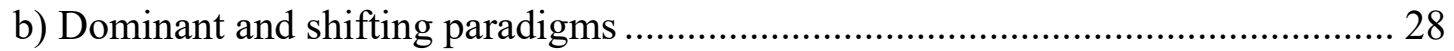

(i) Legal scholars with a clear methodological preference ................................. 29

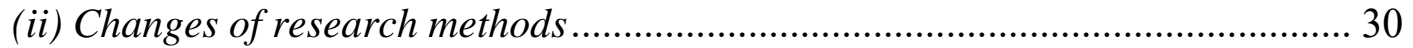

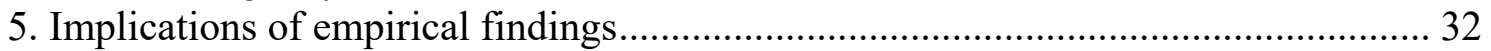

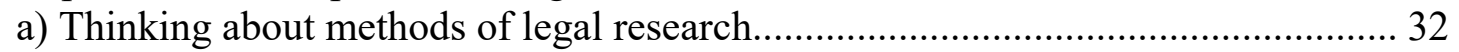

b) Preferences for one or the other research methods ............................................. 33

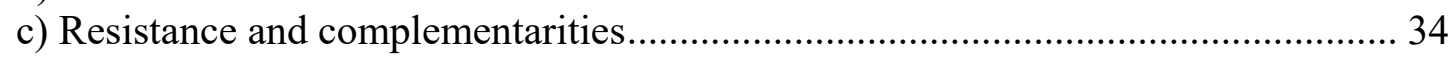

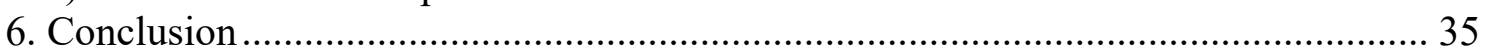

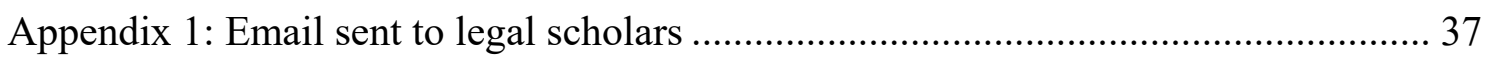

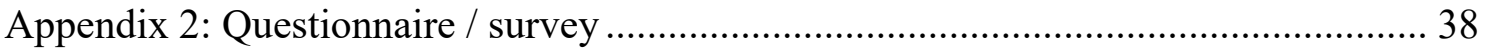




\section{Introduction}

Assume the following scenario: a law professor visits her university cafeteria and wants to sit at a table where she can get some useful comments on the method she plans to use in one of her papers. There are three tables: at the first table sit a historian, a philosopher and a theologian, at the second one an economist, a sociologist and a psychologist, and at the third one a judge, a solicitor and a public prosecutor. Assuming all else being equal (approachability, looks, gender etc.), which table is our law professor likely to join?

This "cafeteria test" aims to illustrate the multiple identities of legal research as part of humanities, as part of social sciences, and as akin to the analysis of law in legal practice. ${ }^{1}$ This paper builds upon our previous work, ${ }^{2}$ where we used this "trichotomy" as a conceptual tool to explain the development of law schools and legal scholarship in the United Kingdom and suggested ways in which these concepts could be tested. By contrast, the current study has an empirical and comparative focus: here, we present the findings of a survey on the research methods identified by academic staff in five law schools, across Germany, Ireland, and the United Kingdom (England and Scotland). The data was collected in autumn 2013 for the purpose of this paper. In the survey we also collected contextual information (e.g., training, career stage). Thus, it is our aim to explore both the relevance of the jurisdiction and law school in which the scholar works and more general factors that may determine preference for one or the other research methods. We also address recent trends, such as the impact of interdisciplinary thinking and the possible "globalization" of legal research. ${ }^{3}$

The collected survey data will be evaluated in a quantitative way. In addition, as we asked respondents to provide comments in free text, these more qualitative responses will also be considered in some detail, in particular in order to understand the role of determinants such as training (or lack of training). Throughout this paper, we will also contextualize our findings with other primary and secondary materials. Thus, overall, our approach may be described as one of "triangulation", namely that we use multiple sources and methods in order to get a fuller picture of the legal scholar's preferences for or against particular methods.

The corresponding structure of this paper is as follows: Section 2 explains the method and conceptual framework of this paper, i.e. our survey method, the law schools studied and the three categories of legal research. Section 3 presents the main results for the five law schools by way of ternary plots. It also interprets these results based on institutional and country differences. Section 4 explores possible further determinants of research preferences. Here we analyse factors such as gender, age, education and subject matter of research. We also identify dominant and changing paradigms in the five law schools. Section 5 addresses the implications of our findings and Section 6 concludes.

\footnotetext{
${ }^{1}$ For a detailed explanation of these categories see $3 \mathrm{c}$, below.

${ }^{2}$ Mathias Siems and Daithí Mac Síthigh, "Mapping Legal Research”, 71 Cambridge Law Journal 651 (2012).

${ }^{3}$ See, e.g., Rob Van Gestel, Hans-Wolfgang Micklitz, and Miguel Poiares Maduro, "Methodology in the New Legal World", EUI Working Papers LAW No. 2012/13, available at http://ssrn.com/abstract=2069872.
} 


\section{Method and conceptual framework}

This paper is based on a survey of academic staff at two German law school (HeinrichHeine University Düsseldorf and Bucerius Law School, Hamburg), two U.K. ones (University of East Anglia [UEA], Norwich, and University of Edinburgh) and one Irish one (Trinity College, University of Dublin ${ }^{4}$ ). The main survey question asked staff members to identify the frequency with which they use different methods of legal research. It is the aim of this section to explain our survey approach as well as its underlying conceptual framework.

\section{a) Units of comparison and respondents}

Our choice of universities and the corresponding countries has been based on substantive but also personal reasons. Analysing three European countries reflects the current debate about research methods in Europe. ${ }^{5}$ It also has the advantage of a "controlled comparison" as far as it can be assumed that European legal cultures are relatively similar, as compared to non-European countries. This may be an obvious statement if one considers differences between European traditions and African or Asian indigenous and religious legal cultures, but there is also the view that there are stark differences between legal research methods in Europe and the United States. For instance, it can be argued that in the continental European civil law countries as well as the islands of the common law (England \& Wales, Ireland, Malta and Cyprus) and the mixed legal system of Scotland a black letter approach to legal research is often still the dominant one. This is said to contrast with the U.S. elite law schools where the interdisciplinary approach has won the day, in particular the economic analysis of law and other research associated with the social sciences. ${ }^{6}$ In the present paper we contribute to this debate through providing empirical evidence for or against any similarity of research methods in four European jurisdictions.

In these jurisdictions we examined five law schools. This approach may be contrasted with one that would conduct a more general survey of all legal scholars. The justification for our method is that we aim for a relatively detailed understanding of particular

\footnotetext{
${ }^{4}$ Trinity College is the single College of the University of Dublin, founded in 1592 by Charter as the "mother of a university" (mater universitatis) with the relationship between the University and College the subject of subsequent debate and litigation. See further David Allardice Webb and Robert Brendan McDowell, Trinity College Dublin: an academic history (Trinity College Dublin Press, 2004), 4.

${ }^{5}$ See, e.g., Martijn Hesselink, “A European Legal Method? On European Private Law and Scientific Method”, 15 European Law Journal 20 (2009); Rob van Gestel and Jan Vranken, “Assessing Legal Research: Sense and Nonsense of Peer Review versus Bibliometrics and the Need for a European Approach", 12 German Law Journal 901 (2011); Rob van Gestel and Hans-Wolfgang Micklitz, "Why Methods Matter in European Legal Scholarship”, 20 European Law Journal 292 (2014).

${ }^{6}$ See, e.g., Martijn W. Hesselink, The New European Legal Culture (Deventer: Kluwer, 2001); Karl Riesenhuber, "English Common Law versus German Systemdenken? Internal versus External Approaches", 7 Utrecht Law Review 117 (2011); Kristoffel R. Grechenig and Martin Gelter, "The Transatlantic Divergence in Legal Thought: American Law and Economics vs. German Doctrinalism”, 31 Hastings International and Comparative Law Review 295 (2008). But see also Carroll Seron, Susan Bibler Coutin, and Pauline White Meeusen, "Is There a Canon of Law and Society?", 9 Annual Review of Law and Social Science 287, 298 (2013) (noting the difference between internal and external perceptions of U.S. legal scholarship).
} 
law schools. Thus, this is akin to "cluster sampling" in statistics. ${ }^{7}$ It is also related to ethnographic fieldwork as anthropologists may often study the population of specific locations in detail in order to understand the more general culture of a particular geographic area.

In the present case, we have not only collected quantitative data, but have also asked legal scholars to self-assess their research and invite them to tell us more about the reasons and influences, as well as change over time. ${ }^{8}$ This approach allows us to capture and explore different aspects of the academic career path and to use this evidence as the basis for highlighting the diversity of experiences and the degree of autonomy of individual scholars.

We chose these five law schools as they are research-focused, but not identical, for instance, in terms of age, size of the student body and esteem indicators. ${ }^{9}$ In addition, because of the relevance of context, we choose institutions that are known to us (at least one of us has worked or studied in each of the five law schools). This also meant that we could get a relatively high response rate. Furthermore, our approach fits within an established practice of "insider" research on academic life ${ }^{10}$

The respondents of our survey were the research-active core members of staff of these five law schools. In respect of the United Kingdom and Ireland, we include all those whose job title is lecturer/assistant professor, senior lecturer, reader, associate professor or professor, but exclude those designated as "adjunct" or "visiting", as well as any other title (e.g., teaching fellow, research fellow). In the case of Germany, we include professors as well as research assistants who either have a $\mathrm{PhD}$ or a substantial contract of employment (at least $50 \%$ of full-time). This was done as to exclude $\mathrm{PhD}$ students who only have a minor involvement, say, in teaching tutorials, and who may therefore be regarded as equivalent to teaching fellows at U.K. universities. These rules were applied both at the point of inviting participation and at confirmation of the final dataset.

\section{b) Procedure of data collection and survey method}

The data discussed in this paper were collected through a web-based survey, which was open during October 2013. The survey was first piloted with a small number of testers (who did not participate in the full survey) and amended for clarity before full release. In the actual survey, subjects were identified through the use of publicly available staff listings (as of 30 September 2013) and the application of consistent criteria, and contacted through their institutional email address. Information on ethics and data protection was included and final explicit consent was sought at the point answers were submitted. In the invitation email and within the survey webpage we gave assurances that names would not be disclosed. Reminders were sent to those who had not responded and the survey was closed at the end of the month.

\footnotetext{
${ }^{7}$ Claus A. Moser and Graham Kalton. Survey Methods in Social Investigation (Aldershot: Dartmouth, 2nd ed., 1979), 100-6.

${ }^{8}$ See also Appendix 2, below.

${ }^{9}$ See 3 a, below.

${ }^{10}$ E.g., Pierre Bourdieu, Homo Academicus (Cambridge: Polity, 1988), 1-35 (justifying to study his own academic field, the French academia); Fiona Cownie, Legal Academics: Culture and Identities (Oxford: Hart Publishing, 2004), 22-5 (on insider research of legal academia).
} 
The survey was available in English for staff of the three institutions in the United Kingdom and Ireland and in German for the two German law schools. Minor customizations were made to reflect differences between jurisdictions and educational structure. For instance, two categories of "senior" and "junior" scholars were created, but expressed in language familiar to each higher education system, i.e. the ranks of lecturer, senior lecturer etc. for the U.K. and Irish universities and those of assistant and professor for the German ones. The precise text of both the invitation emails and the questionnaires is provided in the Appendix to this paper.

In substance, the main aim was to identify the type of legal research method preferred by legal scholars. In this respect, we contemplated various options. First, we could have simply posed an open ended question, i.e. asking the respondents to describe in a free text the methods that they use. This may have been appropriate given that some legal scholars suggest that "legal science" is a "sui generis" discipline, ${ }^{11}$ distinct from the methods used in other parts of the university. In our questionnaire we provided a free text for further comments; however, we also felt that relying on unstructured responses alone may not have been very revealing. The responses may not have been easily comparable. Moreover, given the frequent lack of explicit recognition of methodology, ${ }^{12}$ asking scholars to respond to one or more specific questions has the advantage that it encourages participation and reflection.

Second, it would have been possible to ask specific questions about "objective" proxies and then construct an index according to these responses. For example, such questions could have asked the respondents in which journals they publish, which journals they read, which academic associations they have joined, which conferences they attend etc. However, with this approach it would not have been easy to compare law schools across borders since legal journals, societies and other potential proxies are often specific to the jurisdiction or state in question. More fundamentally, such objective criteria suffer from the reverse problem as the first method, namely that they do not let the individual scholar self-assess the methods that they use.

As a result, we chose an intermediate approach, namely that we provided categories of legal research (based on our earlier work) and then asked respondents to indicate how far they felt that these reflected their own research methods. The respondents could also provide free text comments which about $50 \%$ of them did. This approach is in line with other studies. For example, in a recent study on property law, respondents were asked to self-assess their methods according to seven categories and to comment on "influence or pressure" from their employing institution. ${ }^{13}$ The categories that we used in the present paper were already alluded to in the introduction and will now be explained further.

\footnotetext{
${ }^{11}$ See, e.g., Jan M. Smits, The Mind and Method of the Legal Academic (Cheltenham: Edward Elgar, 2012), 9 (suggesting that this should research what "the law should be"); Jan M. Smits, "Law and Interdisciplinarity: On the Inevitable Normativity of Legal Studies", 1 Critical Analysis of Law 75 (2014) ("question of what the law ought to be").

${ }^{12}$ Noted in van Gestel et al., supra note 3, at 23. See also Hervé Tijssen, De Juridische Dissertatie Onder de Loep: De Verantwoording van Methodologische Keuzes in Juridische Dissertaties (PhD Thesis Tilburg, 2009), available at http://arno.uvt.nl/show.cgi?fid $=94878$ (inter alia, examining the justification of methods in 90 Dutch $\mathrm{PhD}$ theses in law).

${ }^{13}$ Susan Bright and Sarah Blandy, "Survey of Property Law Academics relating to Research Approaches 2013", available at http://www.shef.ac.uk/polopoly_fs/1.302966!/file/PR-Survey-Report.pdf.
} 


\section{c) The three categories of legal research}

There is more than just one way to classify different types of legal research. For example, it has been suggested to distinguish between internal and external methods of legal scholarship, ${ }^{14}$ between doctrinal, reform-oriented, and theoretical legal research, ${ }^{15}$ between micro- and macro legal research, ${ }^{16}$ or between hard and soft, and between pure and applied approaches of legal research. ${ }^{17}$ Following our previous research, this paper uses the categories of "law as humanities", "law as social sciences" and "law as a practical discipline". ${ }^{18}$

The distinction between the humanities and the social sciences (in addition to the natural sciences) is common in the academic literature. ${ }^{19}$ For this project, we are interested in legal research that makes use of the methods of humanities or social sciences, not the substance of the research; we reiterated this point on the face of the survey itself. This can be understood through distinguishing between the use of the methods of a historian (which would mean humanities) and the consideration of ancient cases (which would not necessarily mean this). A similar distinction is made in an article by Jane Baron where she distinguishes between "humanist" and "hermeneutic" law \& literature. $^{20}$

Furthermore, it is worth noting that our survey concerns the methods of humanities or social sciences as used by legal scholars. Thus, we have not surveyed whether and how other disciplines may also engage in legal research - for example, as it has sometimes been argued that the field of "Law and Society" originated by social science scholarship outside the legal academia. ${ }^{21}$ It also clear that the use of particular methods of humanities or social sciences does not necessarily mean collaboration across disciplines. For example, it has recently been argued that socio-legal studies and the welfare state literature share many characteristics but that there is "a strange case of mutual neglect between these two scholarly traditions". 22

The category of "law as a practical discipline" reflects that some legal academics may be "academic lawyers" who share the ethics - and to some extent the methods, ad-

\footnotetext{
${ }^{14}$ Richard L. Schwartz, "Internal and External Method in the Study of Law", 11 Law and Philosophy 179 (1992); Christopher McCruddden, "Legal Research and the Social Sciences", 122 Law Quarterly Review 632 (2006).

15 Terry Hutchinson and Nigel Duncan, "Defining and Describing what we Do: Doctrinal Legal Research", 71 Deakin Law Review 83, 101 (2012) (with reference to the classification of the Australian Pearce Committee in 1987).

${ }^{16}$ Mathias Siems, "Legal Originality”, 28 Oxford Journal of Legal Studies 147 (2008). See also Will Rhee, “The Micro-Macro Legal Continuum and The Levels of Law”, 8 Socio-Legal Review 1 (2012).

${ }^{17}$ Paul Chynoweth, "Legal research", in Andrew Knight and Les Ruddock (eds.), Advanced Research Methods in the Built Environment (Oxford: Wiley-Blackwell, 2008), 28. See also van Gestel and Micklitz, supra note 5, at 305 (law as an instrument for social engineering vs. intrinsic value of law).

${ }^{18}$ For details and further references see Siems and Mac Síthigh, supra note 2, at 653-6.

${ }^{19}$ See, e.g., Jerome Kagan, The Three Cultures Natural Sciences, Social Sciences and the Humanities in the 21st Century (Cambridge: Cambridge University Press, 2009).

${ }^{20}$ Jane B. Baron, "Law, Literature and the Problems of Interdisciplinarity", 108 Yale Law Journal 1059, 1064-5 (1999) ("While humanist law-and-lits argue that lawyers should read literature, others, whom I shall call 'hermeneutic' law-and-lits, argue that lawyers should read literary theory").

${ }^{21}$ For this discussion see Seron et al., supra note 6, at 290-1. See also text accompanying note 120, below.

${ }^{22}$ Daniel Wincott, "Images of welfare in law and society: the British welfare state in comparative perspective", 38 Journal of Law and Society 343, 349 (2011).
} 
justed for the requirements of an academic post - of practicing lawyers. ${ }^{23}$ Thus, these lawyers would mainly be interested in the substance and practical functioning of legal rules - as opposed to the scholarly "why questions". ${ }^{24}$ This partly overlaps with doctrinal legal research, but the latter can also belong to "law as humanities". For example, Mark Van Hoecke identifies legal doctrine "as a mainly hermeneutic discipline, with also empirical, argumentative, logical and normative elements". ${ }^{25}$ Some of these elements have a practical dimension but deep hermeneutical reflections are closer to the humanities.

In this respect, it is also clear that there can be differences between doctrinal scholars from different countries. Since the "law as a practical discipline" category refers to practicing lawyers of the jurisdiction in question, for example, it may matter that in Germany legal practitioners tend to be more "academic" than those in other countries (they often have a PhD in Law; they publish articles in law journals, contribute to books etc.). Similarly, the "humanities" dimension of doctrinal research may have different shades across countries: for example, in England, the long history of the common law may tend towards historical methods whereas the more conceptual thinking of civil law countries may invite the use of more philosophical methods. ${ }^{26}$

In the actual questionnaire we phrased the categories as follows:

"Please assume that there are three main methods of legal research:

- Legal research as part of humanities, i.e. analysis of legal texts (cases, statutes etc) using approaches similar to research in humanities (history, philosophy, literature, theology, etc.)

- Legal research as part of social sciences, i.e. analysis of law in its context, similar to research in social sciences (sociology, economics, psychology etc).

- Legal research as akin to the analysis of law in legal practice, i.e. similar to the approaches used by legal practitioners (judges, solicitors etc.)

In your current research how frequently do you use one of these three approaches? Please allocate in total 10 points (e.g., something like 5/5/0 or 3/3/4).

Note that mixtures can be the result of a mix of these approaches in individual pieces or across various research outputs. Please also note that these categories refer to method not substance."

It can be seen that, on the one hand, the three categories are phrased in a generic language in order not to impose a particular view on how social science, humanities and practical type legal research may be defined. On the other hand, the examples provided in brackets aim to ensure that all respondents will have sufficiently similar comparators,

\footnotetext{
${ }^{23}$ See Tony Becher, Academic Tribes and Territories, Intellectual Enquiry and the Cultures of Disciplines (Milton Keynes: Open University Press, 1989), 8, 30-1, 155.

${ }^{24}$ See van Gestel et al., supra note 3, at 5 (difference between legal scholar and practitioner).

${ }^{25}$ Mark Van Hoecke, "Legal Doctrine: Which Method(s) for What Kind of Discipline?", in Mark Van Hoecke (ed.), Methodologies of Legal Research (Oxford: Hart, 2011), 1, 17.

${ }^{26}$ For common and civil law see also $3 \mathrm{~d}$ (i), below. This may be tested with a so-called "vignette study", i.e. to present respondents with hypotheticals and ask them to assess those in terms of the three categories. For such studies see generally e.g. Christiane Atzmüller and Peter M. Steiner, "Experimental Vignette Studies in Survey Research", 6 European Journal of Research Methods for the Behavioral and Social Sciences 128 (2010).
} 
in terms of discipline (in the first two categories) and practitioners (in the third one) in mind when they answer the question.

The survey question asks respondents to categorize their current research. This approach has the aim to identify patterns of self-identification, namely that it can show who, subjectively, each scholars regards as his or her closest associates, as illustrated by the "cafeteria test" of the introduction to this paper. Asking for such a subjective stance is not uncommon in social surveys. ${ }^{27}$ A possible objection can be that some respondents of such a survey may indicate a preference to a particular type of research because they perceive it to be of higher esteem. But, even if that were to be the case, we content that the aspirations and self-image of legal scholars, in terms of the research they would like to do, are relevant to a discussion of legal scholarship today.

Moreover, we believe that the neutral language of the questions and the anonymous nature of the survey (and it being carried out for an academic project rather than, say, an internal review of research quality) has reduced this risk of such merely aspirational responses as far as feasible. The questions were intended to provoke descriptive responses regarding the methods used, rather than an assessment of quality. We also focused on methods rather than outputs, which necessarily requires attention to how scholars report their own activities. The approach we took (of asking respondents to classify their own methods) is, however, not without risk. Experimental research in psychology and other disciplines suggests, unsurprisingly, a tendency for respondents to overstate positive characteristics when asked to classify or rate themselves (as compared with third parties), even when the risk of bias is specifically drawn to their attention. ${ }^{28}$ There can also be understatement where the assessment is perceived as being of a "difficult" task, ${ }^{29}$ which could be a factor in relation to self-assessment of methods. We guarded against this through avoiding the use of language that suggests merit or virtue (or the opposites), and scrutinized free text comments for any evidence that this was a factor. It has also been argued that "overplacement" by participants is not as problematic as initially thought, ${ }^{30}$ that self-enhancing biases, while flawed, deserve study because of their contribution to behavior, ${ }^{31}$ and that study of "possible selves" can be appropriate and rewarding. ${ }^{32}$ As such, we contend that the results give a realistic depiction of methods used and believed to be used by the population studied.

The possibility of mixtures in the survey question can also be related to the "cafeteria test". For example, our law professor may work on various papers and for one paper she may like to get some feedback from social scientists but for another one from legal practitioners or humanities scholars. It could also be the case that she responds that she would like to talk to a mixed group, say, one judge, one economist and one historian:

\footnotetext{
${ }^{27}$ See, e.g., Transparency International's Corruption Perception Indices, http://cpi.transparency.org.

${ }^{28}$ Emily Pronin, Daniel Yin and Lee Ross, "The Bias Blind Spot: Perceptions Of Bias In Self Versus Others", 28 Personal and Social Psychology Bulletin 369, 378 (2002).

${ }^{29}$ Don Moore, "Not so Above Average After All: When People Believe They Are Worse Than Average and Its Implications for Theories of Bias in Social Comparison", 102 Organizational Behavior and Human Decision Processes 42 (2007).

${ }^{30}$ Jean-Pierre Benoit and Juan Dubra, “Apparent Overconfidence”, 79 Econometrica 1591 (2011).

${ }^{31}$ Constantine Sedikides and Aiden Gregg, "Portraits Of The Self" in Michael Hogg and Joel Cooper (eds.), SAGE Handbook of Social Psychology (London: Sage, 2003).

${ }^{32}$ See contributions in Curtis Denkel and Jennifer Kerpelman (eds.), Possible Selves: Theory, Research and Applications (New York: Nova, 2006).
} 
again, then, this would indicate that this professor would presumably assign intermediate scores for each of the three categories.

\section{Main results for five law schools in four jurisdictions}

As the previous section explained, our empirical study focussed on five law schools in Germany, the United Kingdom and Ireland. This section presents the main results. It starts with summary information on these law schools. We then present and interpret our results, based on institutional and country differences. The anonymized data collected in the survey are available at an accompanying project website. ${ }^{33}$

\section{a) The five law schools and its academic staff}

The schools vary in age, institutional mission, jurisdiction, and other features. Table 1 provides an overview of these differences, identified at the time of the survey in October 2013 .

Table 1: Summary information on the law schools of this study

\begin{tabular}{|l|l|c|c|c|l|l|}
\hline & $\begin{array}{c}\text { Coun- } \\
\text { try }\end{array}$ & $\begin{array}{c}\text { Law } \\
\text { school } \\
\text { approx. } \\
\text { student \# }\end{array}$ & $\begin{array}{c}\text { Law school } \\
\text { academic } \\
\text { staff \# (and } \\
\text { responses) }\end{array}$ & $\begin{array}{c}\text { Institution } \\
\text { (and law } \\
\text { school) } \\
\text { age }\end{array}$ & $\begin{array}{l}\text { Structure of } \\
\text { law school } \\
\text { within uni- } \\
\text { versity }\end{array}$ & \multicolumn{1}{|c|}{$\begin{array}{c}\text { Esteem } \\
\text { indicators }\end{array}$} \\
\hline $\begin{array}{l}\text { Bu- } \\
\text { cerius }\end{array}$ & $\begin{array}{l}\text { Ger- } \\
\text { many }\end{array}$ & 960 & $\begin{array}{c}\text { max. 94 } \\
(14)\end{array}$ & 2000 & $\begin{array}{l}\text { Law-only } \\
\text { private uni- } \\
\text { versity }\end{array}$ & $\begin{array}{l}\text { Top 10 in German } \\
\text { law school rank- } \\
\text { ings }\end{array}$ \\
\hline $\begin{array}{l}\text { Düs- } \\
\text { seldorf }\end{array}$ & $\begin{array}{l}\text { Ger- } \\
\text { many }\end{array}$ & 1200 & $\begin{array}{c}\text { max. 118 } \\
(23)\end{array}$ & $\begin{array}{c}1965 \\
(1993)\end{array}$ & $\begin{array}{l}\text { Faculty of } \\
\text { Law }\end{array}$ & $\begin{array}{l}\text { Above average in } \\
\text { CHE ranking for } \\
\text { German law } \\
\text { schools }\end{array}$ \\
\hline $\begin{array}{l}\text { Edin- } \\
\text { burgh }\end{array}$ & $\begin{array}{l}\text { U.K. } \\
\text { (Scot- } \\
\text { land) }\end{array}$ & 1500 & $60(42)$ & $\begin{array}{l}1583 \\
(1707)\end{array}$ & $\begin{array}{l}\text { College of } \\
\text { Humanities } \\
\text { \& Social } \\
\text { Sciences }\end{array}$ & $\begin{array}{l}\text { Member of Russell } \\
\text { Group and Coimbra } \\
\text { Group; law school } \\
\text { ranked in top 10 of } \\
\text { RAE 2008 }\end{array}$ \\
\hline
\end{tabular}

\footnotetext{
${ }^{33}$ See http://www.mappingmethods.blogspot.com/.

${ }^{34}$ For the contentious role of rankings see Rob van Gestel, "Sense and Non-sense of a European Ranking of Law Schools and Law Journals”, 35 Legal Studies 165 (2015).

35 http://www.law-school.de/rankings.html?\&L=0

${ }^{36}$ http://ranking.zeit.de/che2013/.

${ }^{37}$ http://www.ed.ac.uk/about/mission-governance/affiliations; http://www.ed.ac.uk/about/edinburghglobal/partnerships/global-networks; http://www2.law.ed.ac.uk/research/rae2008.aspx.
} 


\begin{tabular}{|l|l|c|c|c|l|l|}
\hline UEA & $\begin{array}{l}\text { U.K. } \\
\text { (Eng- } \\
\text { land) }\end{array}$ & 600 & $32(19)$ & $\begin{array}{c}1963 \\
(1977)\end{array}$ & $\begin{array}{l}\text { Faculty of } \\
\text { Social Sci- } \\
\text { ences }\end{array}$ & $\begin{array}{l}\text { Top 20 in Times } \\
\text { Higher Education } \\
\text { 2013 global ranking } \\
\text { of "under 50" uni- } \\
\text { versities }\end{array}$ \\
\hline Dublin & Ireland & 1000 & $22(13)$ & $\begin{array}{c}1592 \\
(1740)\end{array}$ & $\begin{array}{l}\text { Faculty of } \\
\text { Arts, Hu- } \\
\text { manities \& } \\
\text { Social Sci- } \\
\text { ences }\end{array}$ & $\begin{array}{l}\text { Highest ranked } \\
\text { Irish university; } \\
\text { member of Coim- } \\
\text { bra Group }\end{array}$ \\
\hline
\end{tabular}

In online surveys it is often difficult to achieve a decent response rate. ${ }^{40}$ In this respect, the information on the numbers of academic staff and their responses in Table 1 requires further explanation. With respect to the two German law schools, we aimed to include professors as well as research assistants who either have a $\mathrm{PhD}$ or a substantial contract of employment (at least $50 \%$ of full-time), in order to achieve reasonable comparability with the grade of Lecturer and above in the United Kingdom and Ireland. ${ }^{41}$ However, the university websites do not indicate the type of employment contract; many of the research assistants that we contacted (the "max." numbers in Table 1) may not have been eligible for this study. If one considers only those who we know to be eligible (the professors and assistants who already have a $\mathrm{PhD}$ ), the response rates were $37 \%$ and $32 \%$ for the two German law schools. ${ }^{42}$ With respect to other three law schools, the response rates were even higher: $70 \%$ for Edinburgh and 59\% for Dublin and UEA. Thus, overall, the response rates are very good, as compared with other studies in this field. ${ }^{43}$ Half of the respondents also provided comments in the free text field of the survey. ${ }^{44}$

\section{b) Visual presentation of main results}

There are different ways of presenting the data collected in our survey. A simple way of comparing the research preferences between the five law schools is to calculate the arithmetic means and present those in a bar chart:

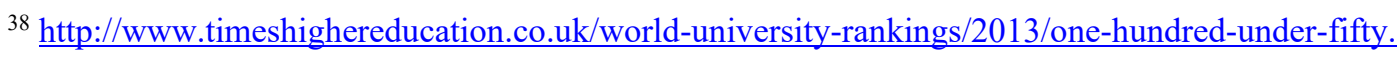

${ }^{39} \mathrm{http} / / / w w w . t c d . i e / a b o u t /$ facts/; http://www.tcd.ie/globalrelations/global-reach/.

${ }^{40}$ See, e.g., Mick P. Couper and Michael Bosnjak, "Internet surveys", in Peter V. Marsden and James D. Vright (eds.), Handbook of Survey Research (Bingley: Emerald, 2nd ed. 2010), 536-8 (noting the particular challenges of achieving high response rates for online surveys).

${ }^{41}$ See 2 a, above.

${ }^{42}$ The precise numbers are 11 out of 30 for Bucerius and 9 out of 28 for Düsseldorf.

${ }^{43}$ See, e.g., Duncan D. Nulty, "The Adequacy of Response Rates to Online and Paper Surveys: What Can be Done?", 33 Assessment \& Evaluation in Higher Education 301, 303 (2008) (citing eight studies with an average response rate of 33\%); Willem van Boom and Rob van Gestel, "Rechtswetenschappelijk onderzoek - Uitkomsten van een landelijke enquête", Nederlands Juristenblad (2015) web-version available at http://njb.nl/Uploads/2015/5/Van-Boom-en-Van-Gestel-2015.pdf (response rates between 13 and $29 \%$ for survey at all ten Dutch law schools).

${ }^{44}$ These comments are also available on the project website, supra note 33, and they reflect the diverse research preferences as discussed in the following.
} 
Figure 1: Research methods per university

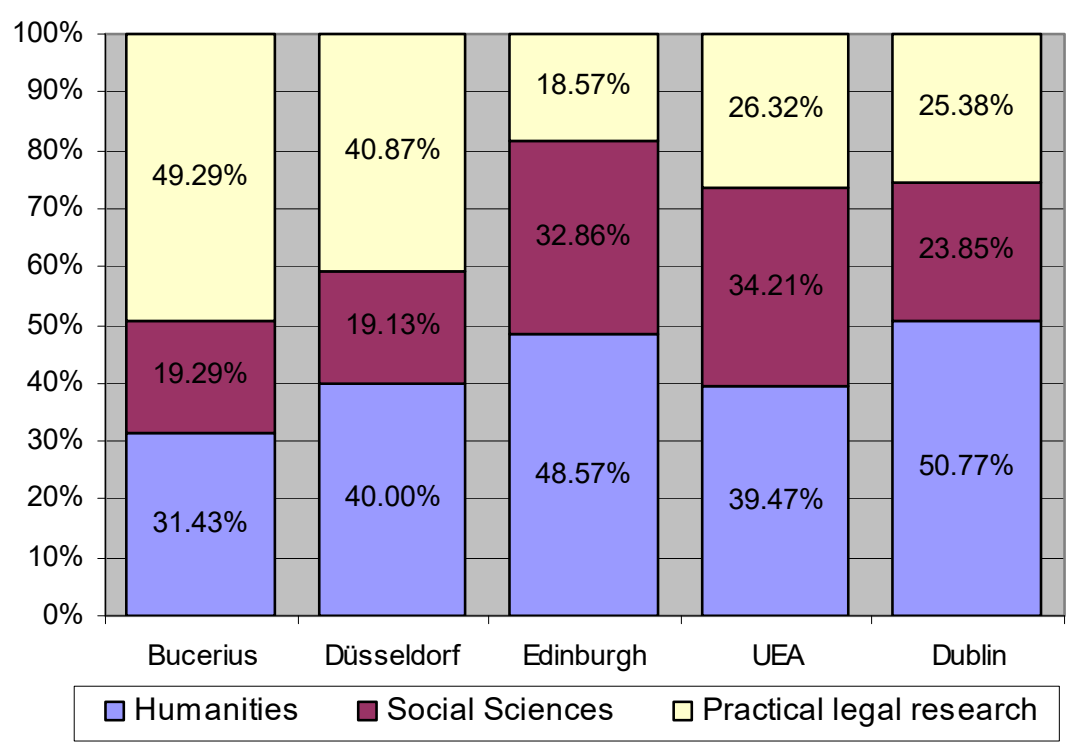

The problem with Figure 1 is, however, that it does not show the individual responses and the corresponding spread of the data. Thus, as already explained in our previous work, it is also useful to visually represent the relative presence of the three broad categories through "ternary plots". ${ }^{45}$ The ternary plot, most familiar in the sciences, is an adaption of a Cartesian diagram for the particular circumstances of "three dimensional" responses or observations. While we explore the data in more detail in this section (by institution) and in section 4 (in terms of demographics), the ternary plot allows the reader to view the positioning of all respondents with ease, and assists with the identification of broad trends or themes.

The following diagrams of Figure 2 include all responses, with larger markings indicating more than one respondent with identical responses The arithmetic mean is identified as blue circles. We also highlight, in red stars, the "centre" of the dataset. The estimated centre, calculated with the compositional data analysis software CoDaPack, may be more appropriate than the mean for the particular data we have collected and the geometric form in which it is presented. ${ }^{46}$ Although the means and centers are closely aligned in our results, the mean is more affected by outlying results - for instance, the cluster of "social science only" respondents in Edinburgh pulled the mean away from the core of responses.

\footnotetext{
${ }^{45}$ Siems and Mac Síthigh, supra note 2, at 668-9.

${ }^{46}$ John Aitchison, "A concise guide to compositional data analysis" (2005), available at http://ima.udg.edu/activitats/codawork05/A concise_guide to compositional data analysis.pdf at p. 49; Glòria Mateu-Figueras et al, "The principle of working on coordinates", in Vera Pawlowsky-Glahn and Antonella Buccianti (eds.), Compositional Data Analysis: Theory and Applications (Chichester: Wiley, 2011), 40. For these calculations some adjustment of the "zero" responses was necessary. As in the present case those can be treated as "rounded zeros", we replaced them with the value " 0.25 " (the average between $0.00 . .1$ and 0.499 ..) and made corresponding changes to other values. This procedure is based on Josep A. Martin-Fernandez, Carles Barcelo-Vidal, and Vera Pawlowsky-Glahn, "Dealing With Zeros and Missing Values in Compositional Data Sets Using Nonparametric Imputation", 35 Mathematical Geology 253 (2003).
} 
Figure 2: Research preferences of academics in five law schools

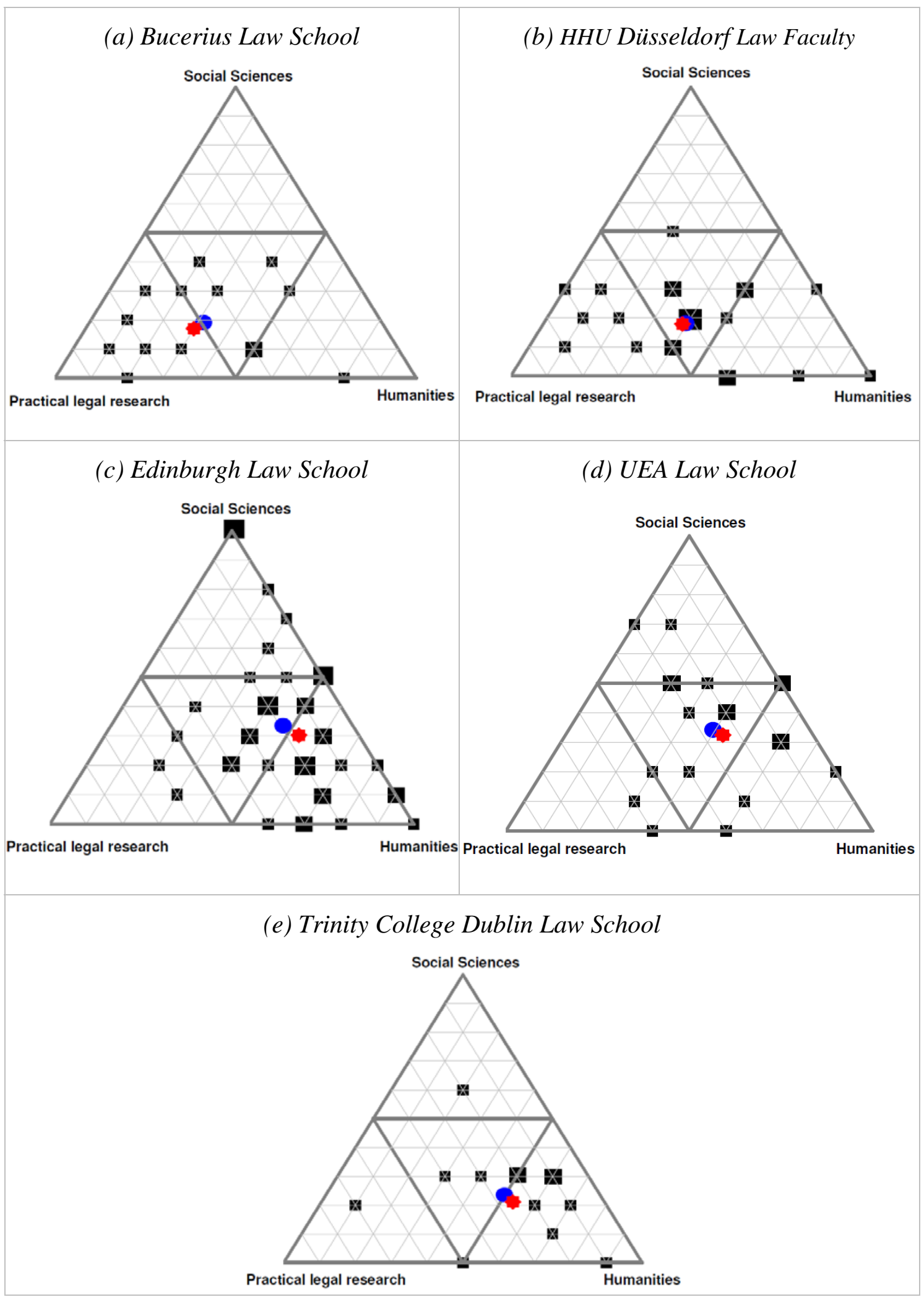


Compositional statistics also allows for the calculation of the spread of the data, known as the CLR variance ("centered log-ratio transformation"). This is the equivalent to calculating the standard deviations in classical statistics.

Table 2: CLR variances for the five law schools

\begin{tabular}{|l|c|c|c|c|}
\hline & humanities & $\begin{array}{c}\text { social sci- } \\
\text { ences }\end{array}$ & $\begin{array}{c}\text { practical le- } \\
\text { gal research }\end{array}$ & $\begin{array}{c}\text { total vari- } \\
\text { ance }\end{array}$ \\
\hline Bucerius & 0.44 & 0.45 & 0.39 & 1.27 \\
\hline Düsseldorf & 0.74 & 0.57 & 0.60 & 1.90 \\
\hline Edinburgh & 0.75 & 1.03 & 0.79 & 2.57 \\
\hline UEA & 0.71 & 0.80 & 0.79 & 2.31 \\
\hline Dublin & 0.47 & 0.48 & 0.42 & 1.37 \\
\hline All law schools & 0.73 & 0.84 & 0.79 & 2.37 \\
\hline
\end{tabular}

Table 2 shows that the two schools in the United Kingdom have "more variance" - as we discuss below. The high value for social science variance in the same schools, as compared with the other three schools, reflects what is visible on the ternary plots - a group of respondents who identify strongly with social science (exclusively or to a very great extent). However, in all cases, the variance data demonstrates how the humanities category is more widely accepted (or less unusual) than that for social sciences.

\section{c) Interpretation based on institutional differences}

The findings can be contextualized by considering the focus of the law schools we studied. This focus is identified, first and foremost, from the public documents of the school and (where relevant) the institution in which it is located. Some of this information is presented in Table 1, above.

We note general consistency with the reputation or priorities of the schools. Starting with Germany, the traditional system of publicly funded universities means that German universities are relatively similar: all of them have decent resources but without some of them being "global elite universities". ${ }^{47}$ Correspondingly, the law faculty of the University of Düsseldorf can be seen as a relatively typical German law school. The predominant mix of practical and humanities-influenced legal research is a general feature of German legal scholarship. ${ }^{48}$ The law school's website shows, on the one hand, the traditional focus of a German law school on preparing students for the First Exam (which can mainly be associated with the practical dimension). ${ }^{49}$ On the other hand, information on international collaborations, various research centers and specialized master degrees ${ }^{50}$ indicates that the law school has also developed a wider range of activities.

\footnotetext{
${ }^{47}$ By way of illustration see U21 Ranking of National Higher Education Systems 2014, available at http://www.universitas21.com/RelatedFile/Download/589 where Germany ranks 14 out of 50 countries and the THE World University Rankings, available at http://www.timeshighereducation.co.uk/worlduniversity-rankings/2013-14/world-ranking where there is no German university in the top 50.

${ }^{48}$ See 3 d, below.

${ }^{49} \mathrm{http}: / / w w w . j u r a . h h u . d e /$ studium.html.

${ }^{50}$ See http://www.jura.hhu.de/internationales.html, http://www.jura.hhu.de/forschung/forschung-an-deninstituten.html, http://www.duslaw.de/studiengaenge-llm.html.
} 
With respect to Bucerius Law School, our survey data show that the practical category is the main subject of emphasis. This is in line with the fact that Bucerius, as a private law school, collaborates closely with law firms, setting out in its mission statement how "the course of studies is based on a unity of teaching and research, and merges the needs of the practicing legal community with an academic pervasion of the law" and acknowledging how "donations from private sponsors are a sign of the society's confidence in the Law School"; ${ }^{51}$ some facilities are named after major law firms. It is also important to note that undergraduate students pay tuition fees at Bucerius, unlike students at most German public universities. As a result, students expect to receive an excellent and "practical" legal education, ${ }^{52}$ in order to get into the top jobs in legal practice after graduation. This may also have a side-effect on the practical research focus at Bucerius. ${ }^{53}$

The survey results for Edinburgh and UEA are relatively mixed as regards the preferences for particular research methods. This is in line with a statement on Edinburgh's website which identifies as its first core strategic objective the building of "a research profile of depth and breadth which has demonstrable and transformative impact (academic, legal and social)" ${ }^{54}$ Yet, it is also worth noting that, according to our findings, Edinburgh only has a relatively small number of scholars who identify their research as falling within our "practical" category. This may reflect the nature of one of the top ten U.K. law schools where practical legal research is often seen as not "original" enough, in particular for the purposes of the U.K. Research Assessment Exercises (RAEs, now REFs). ${ }^{55}$

Furthermore, it is worth noting that, unlike the other three law schools, Edinburgh and UEA have a good number of scholars that associate themselves with the social sciences. This reflects the existence of clusters or centers explicitly framed in relation to the social sciences at both of these law schools. ${ }^{56}$ It is also in line with some of the programs they offer: Edinburgh's interest in criminology supports an MSc in this field and UEA offers a Masters in Research in "social science research methods" as well as degrees in obviously interdisciplinary areas such as competition and media.

Social science methods appear less prominent in Dublin than in the two U.K. institutions. Although the response rate was lower here, the results are not entirely unexpected. Legal education in Ireland has long been closely linked with the small, self-employed Bar. In some universities, many full-time members of academic staff will continue to practice law, and the value of practical and clinical training within undergraduate legal education has been reasserted, although managerial approaches to workload are making it more difficult for full-time academic staff to practice law. ${ }^{57}$ Trinity College itself is identified with performing particularly well in rankings that concentrate on "arts and humanities". 58

\footnotetext{
${ }^{51} \mathrm{http} / / / \mathrm{www}$. law-school.de/leitbild.html?\&L=1.

${ }^{52}$ See also Christoph Luschin, "A German Ivy? The Bucerius Law School”, 19 Southwestern Journal of International Law 1 (2012).

${ }^{53}$ The relationship between teaching and research preferences is also discussed in $3 \mathrm{~d}$ (ii), below.

${ }^{54} \mathrm{http} / / / \mathrm{www}$.law.ed.ac.uk/other areas of interest/about/about edinburgh law school/strategy and vision.

${ }^{55}$ For the RAEs see also $3 \mathrm{~d}$ (ii), below.

${ }^{56}$ At Edinburgh, the Criminology group since the 1970s (http://www2.law.ed.ac.uk/criminology/); at UEA, the ESRC-funded Centre for Competition Policy (http://www.competitionpolicy.ac.uk).

${ }^{57}$ Marie-Luce Paris and Lawrence Donnelly, "Legal Education in Ireland: A Paradigm Shift to the Practical?", 11 German Law Journal 1067, 1079 (2010).

${ }^{58} \mathrm{https}: / / w w w . t c d . i e / C o m m u n i c a t i o n s / n e w s / n e w s . p h p ? h e a d e r I D=1872 \& v s$ date=2011-6-1.
} 


\section{d) Interpretation based on country differences}

It is also possible to relate our findings to differences between the countries of our study. The two German law schools show a mixture of practical and humanities related legal research. Yet the humanities focus is strong across all the schools we studied, for instance also in Dublin, thus, possibly reflecting the European approach to law as humanities more generally. The two U.K. law schools show the greatest internal diversity, possibly due to the major changes that have happened across the U.K. universities in the last quarter-century, as the following will explain.

\section{(i) The role of legal families}

The most intuitive reason for these differences may be that legal systems and methods are very different, perhaps because there is a deep divide between common and civil law countries. The European scope of our study does not enable us to provide a general answer to the relevance of legal family classifications. Indeed, previous research ${ }^{59}$ has found that today U.S. law and legal culture is very different from both the United Kingdom and continental Europe. Still, of course, there may also be differences within Europe. Although ideas do indeed travel, especially as joint projects are increasingly favored in funding systems (e.g. requirements for cross-border collaboration in EUfunded schemes), differences in legal thinking persist.

For example, primers on legal research for postgraduate and doctoral students demonstrate how those groups are introduced to legal skills and aspects of (legal) philosophy in Germany. ${ }^{60}$ On the contrary, similar texts for U.K. researchers include a mixture of methods: historical, comparative, doctrinal, socio-legal, and quantitative. ${ }^{61}$ This itself is a development; as our respondents - in the free text of our survey - told us that the lack of social science training in the past continues to inhibit even successful, midcareer scholars from making use of these methods. ${ }^{62}$

We may also need to consider that the United Kingdom is not a uniform legal system, and that Scotland is sometimes seen as belonging to a separate "mixed legal family". ${ }^{63}$ Having asked Edinburgh respondents whether they have received their undergraduate training in Scotland or elsewhere, we could calculate that the arithmetic means within the sub-category of Scots lawyers from Edinburgh (15 respondents) are $43 \%$ for

\footnotetext{
${ }^{59}$ See references in supra note 6.

${ }^{60}$ E.g., Karl Larenz and Claus-Wilhelm Canaris, Methodenlehre der Rechtswissenschaft (Berlin: Springer 3rd ed. 1995); Bernd Rüthers, Christian Fischer and Axel Birk, Rechtstheorie: mit Juristischer Methodenlehre (Munich: Beck, 7th ed. 2013).

${ }^{61}$ E.g., Mike McConville and Wing Hong Chui (eds.), Research Methods for Law (Edinburgh: Edinburgh University Press 2007); Dawn Watkins and Mandy Burton (eds.), Research Methods in Law (London: Routledge 2013).

${ }^{62}$ Respondents EDI 15, EDI 21, TCD 9. For similar assessments see Michael Adler and Jonathan Simon, "Stepwise Progression: The Past, Present, and Possible Future of Empirical Research on Law in the United States and the United Kingdom", 41 Journal of Law and Society 173, 188-191 (2014); Hazel Genn et al., Law in the Real World: Improving our Understanding of How Law Works (2006), available at http://www.nuffieldfoundation.org/nuffield-inquiry-empirical-legal-research-law-real-world. For the role of education see also 4 a (ii), below.

${ }^{63}$ For the debate see, e.g., Sue Farran, "Scots Law: A System in Search of a Family?", 61 Northern Ireland Legal Quarterly 311 (2010).
} 
law as humanities, $36 \%$ for law as social sciences and $15 \%$ for practical legal research. This is fairly close to the overall Edinburgh data for all 42 staff members: ${ }^{64}$ thus, this suggests that, in terms of these three general legal methods, Scotland is not very different from the rest of the United Kingdom.

\section{(ii) Further factors, in particular higher education}

According to Tony Becher, even where the subject matter of particular fields appears to be global (e.g., in physics or engineering) "geographical variation" of disciplines still exists as the methods of researchers may reflect "identifiable features of a particular society, such as its education system or its level of economic development". ${ }^{65}$ Even more so, this is likely to be the case in legal scholarship where such factors may complement differences in legal culture and style. In the following, we cannot identify all cultural, psychological, social, political, economic or other factors which may determine why, say, the average English and German scholar do legal research in a different way. Rather, the following will focus on factors of higher education as these have been particular controversial in recent years.

University structures do differ between institutions. In Germany, Immanuel Kant referred to law as being, along with medicine and theology, one of the three "higher faculties" ${ }^{66}$ But in the United Kingdom, the "predominant notion of academic lawyers is that they are not really academic". ${ }^{67}$ Is this still a fair summary, now that legal scholars are subject to the same research assessments and research-focused promotion criteria as other academics, and often share faculties and research council budgets with them?

Incentive structures have not converged. Differences between the governance and funding of institutions between countries may relate to research. In the United Kingdom, for example, both the funding and the reputation of an institution will be affected by the external review of the quality of the research outputs of its staff, in the Research Excellence Framework (REF; until 2014 called RAE, Research Assessment Exercise), where work is evaluated against criteria of significance, originality and rigour. ${ }^{68}$ In the free text some of our respondents also made explicit reference to the importance of the REF for changes in legal scholarship, appearing to assume that these criteria are more obviously met in the case of work in humanities and in particular social science: one of them proposed that approaches beyond "black letter domestic" made it more likely that such work would be reviewed at the valued levels of $3^{*}$ and $4^{*}$ under the REF, and another pointed to the "positive" impact of the REF in promoting quality and thus a move towards humanities and social science approaches over time. ${ }^{69}$

In Ireland, on the contrary, there is no equivalent system. ${ }^{70}$ Nor is there one in Germany: academics are required to produce internal reports about research activity, but

\footnotetext{
${ }^{64}$ See b, above.

${ }^{65}$ Becher, supra note 23, at 21-2.

${ }^{66}$ Immanuel Kant, Der Streit der Fakultäten (1789) - English translation by Mary J. Gregor, The Conflict of the Faculties (Lincoln: University of Nebraska Press 1992).

${ }^{67}$ Becher, supra note 23, at 30.

${ }^{68} \mathrm{http}$ ://www.ref.ac.uk/. See also Cownie, supra note 10, at 135-8 (RAE effect, as "increasingly important place of research in the culture of academic law").

${ }^{69}$ Respondents UEA 16, EDI 23.

${ }^{70}$ Key Perspectives Ltd, “A Comparative Review of Research Assessment Regimes in Five Countries and the Role of Libraries in the Research Assessment Process" (2009), available at
} 
professors in publicly-funded institutions enjoy strong protection against the termination of their employment. This is stronger than is the case in the United Kingdom, where the Education Reform Act 1988 provides for the amendment of university statutes so as to allow dismissal of academic staff on the grounds of redundancy or good cause (s. 203). More recently, institutions have made use of "teaching-only contracts" and redeployed staff considered to be performing less effectively in research (especially with a view to the REF) to these contracts, or advertized more of these positions than before. ${ }^{71}$

Previous research has also pointed to variation between countries in the form and position of disciplinary boundaries. It is argued that, despite some convergence as a consequence of the Bologna Process and world and EU trade law, German and U.K. higher education systems still differ in their approach to the vocational dimension and to basic/applied research - and the fates of the social sciences and humanities are different as a result. ${ }^{72}$ None of the countries we considered take the Swedish approach of defining at a national level the disciplines that are part of the social sciences or humanities, and so the autonomy of German, U.K. and Irish institutions means that there can be variation across institutions, as well as across countries. ${ }^{73}$

Our focus in this paper is on legal research. However, the approach of an institution to teaching also makes a difference - such as in choosing who to appoint and whether to promote a member of staff. The development of research methodologies, therefore, may compete for attention with responses to other incentives (e.g., the development of new courses, taking on administrative roles). There is clear potential for tension between research and teaching, ${ }^{74}$ although the separation of function that has emerged in the United States (where much teaching may be "outsourced", in some institutions, to adjunct professors and temporary staff) is less obvious in the countries we have considered in this study. ${ }^{75}$

The tension between teaching and research is likely to be more pronounced in the United Kingdom than in the other countries of this study. Due to the RAEs/REFs, the claim that "in Common Law countries (...) most full-time professors think of themselves

http://www.oclc.org/content/dam/research/publications/library/2009/2009-09.pdf?urlm=162926, at pp. 23-26.

${ }^{71}$ See, e.g., Paul Jump, "Swansea's tough REF plans provoke disquiet” (Times Higher Education 5 September 2013) (commenting on the proposed move of staff without four $3^{*}$ publications from a contract with 6 hours per week of teaching to one with 18 hours); Anna Fazackerley, "University reputation: will teachers pay the price?" (The Guardian 30 April 2013), available at http://www.theguardian.com/education/2013/apr/29/university-research-funding-harms-teaching (reviewing different positions taken by U.K. institutions on the consequences of non-submission to the REF for academic staff contracts).

${ }^{72}$ Rebecca Krebs and Silke Wenk, "Disciplinary barriers between the social sciences and humanities" (2005), available at http://www.york.ac.uk/res/researchintegration/ComparativeReports/Comparative_Report_Construction_o f Knowledge.pdf at pp. 7-11.

${ }^{73}$ Ursula Apitzsch and Irini Siouti, "Comparative report on the infrastructural definitions of the humanities and social sciences in eight European countries" (2005), available at

http://www.york.ac.uk/res/researchintegration/ComparativeReports/Comparative Report Infrastructural Definitions.pdf.

${ }^{74}$ van Gestel and Micklitz, supra note 5, at 300 .

${ }^{75}$ For the discussion about such a split see Mathias Siems, "A World Without Law Professors", in Mark Van Hoecke (ed.), Methodologies of Legal Research (Oxford: Hart Publishing, 2011), 71-86. 
mainly as teachers rather than scholars", ${ }^{76}$ is certainly not accurate any more for England and other parts of the United Kingdom. Thus, U.K. legal scholars may often feel that, for their research, they should not be "too practical" as this may not help one's academic career, while in their teaching they should not be "too theoretical" lest students complain that they do not get "value for money" given the constant rise in student tuition fees. ${ }^{77}$ In Germany, by contrast, the more practical research focus means that this tension is less pronounced. Moreover, the fact that the Final Exam is predominantly managed by the Ministries of Justice (not the universities) ${ }^{78}$ further stimulates the frequent emphasis on practical legal knowledge.

\section{Possible determinants of research preferences}

The previous section highlighted the country and institutional differences between the law schools of our study. In this section, we consider the role of various themes that may shape the research preferences of individual academics. In particular, we analyze factors such as gender, age, education and subject matter of research (see a, below). We also identify dominant and changing paradigms in the five law schools (see b, below).

Despite the aim to identify possible determinants, this paper does not use tools of inferential statistics, such as regression analysis. In the present context, it is often difficult to identify a clear unidirectional causal relationship: for example, if it were found that private lawyers had a preference for practical legal research, this would not necessarily mean that doing research on private law leads to a more practical approach, because it could also be the case that scholars who prefer to do practical legal approach then decide to do focus on topics of private law. There may also be cases where the decision to enter the academic career in law is dependent on whether one's preferred method of research is accepted in a particular market: for example, if persons with a degree from another discipline are less likely to associate with a practical approach, a market where the latter is dominant may see few of those academics.

As previously explained, ${ }^{79}$ it is the general aim of this paper to provide a nuanced picture of the situation in a small number of law schools familiar to us. In the following section we also present some aggregates of the five law schools. This may invite the response that these five units are not a representative sample, say, of law schools in Europe, or representative of the country in which they are located. To reflect this point, the following will also report to what extent a particular result holds for all of the five law schools, or whether there may be an outlier.

\footnotetext{
${ }^{76}$ David S. Clark, "The Organization of Lawyers and Judges" in Mauro Cappelletti (ed.), International Encyclopedia of Comparative Law, volume 16 (Tübingen: Mohr 2002) para. 56.

${ }^{77}$ Similar the assessment by Hilary Somerlad et al., The Futures of Legal Education and the Legal Profession (Oxford: Hart Publishing 2015), 14 ("in essence the law school curriculum remains doctrinal and traditional"). For the fee structure in U.K. universities see http://www.ucas.com/how-it-all-works/studentfinance/undergraduate-student-finance.

${ }^{78}$ According to $\S 5 \mathrm{~d}(2)$ of the German Judiciary Act (Richtergesetz) this concerns $70 \%$ of the First Exam, while $30 \%$ of this exam is set by the universities.

${ }^{79}$ See 2 a, above.
} 


\section{a) Analysis of possible general determinants}

The survey, underlying this paper, not only identified preferences in research methods, but asked respondents to provide information on a number of further personal characteristics. ${ }^{80}$ Table 3 reports the results across the five law schools. The shadings highlight law schools that are $10 \%$ above or below the percentages of the "Total" column.

Table 3: Variables (absolute counts, and \% of respondents of each law school)

\begin{tabular}{|c|c|c|c|c|c|c|c|}
\hline & & Bucerius & Düsseldorf & Edinburgh & UEA & Dublin & Total \\
\hline \multirow[t]{4}{*}{ Gender } & \multirow[t]{2}{*}{ Male } & 11 & 18 & 22 & 13 & 5 & 69 \\
\hline & & $78.6 \%$ & $78.3 \%$ & $52.4 \%$ & $68.4 \%$ & $38.5 \%$ & $62.2 \%$ \\
\hline & \multirow[t]{2}{*}{ Female } & 3 & 5 & 20 & 6 & 8 & 42 \\
\hline & & $21.4 \%$ & $21.7 \%$ & $47.6 \%$ & $31.6 \%$ & $61.5 \%$ & $37.8 \%$ \\
\hline \multirow[t]{6}{*}{ Age } & \multirow[t]{2}{*}{$\leq 35$} & 7 & 14 & 12 & 8 & 3 & 44 \\
\hline & & $50.0 \%$ & $60.9 \%$ & $28.6 \%$ & $42.1 \%$ & $23.1 \%$ & $39.6 \%$ \\
\hline & \multirow[t]{2}{*}{$36-49$} & 5 & 5 & 19 & 8 & 8 & 45 \\
\hline & & $35.7 \%$ & $21.7 \%$ & $45.2 \%$ & $42.1 \%$ & $61.5 \%$ & $40.5 \%$ \\
\hline & \multirow[t]{2}{*}{$\geq 50$} & 2 & 4 & 11 & 3 & 2 & 22 \\
\hline & & $14.3 \%$ & $17.4 \%$ & $26.2 \%$ & $15.8 \%$ & $15.4 \%$ & $19.8 \%$ \\
\hline \multirow[t]{4}{*}{ Rank } & \multirow[t]{2}{*}{ Junior staff } & 7 & 16 & 20 & 10 & 5 & 58 \\
\hline & & $50.0 \%$ & $69.6 \%$ & $47.6 \%$ & $52.6 \%$ & $38.5 \%$ & $52.3 \%$ \\
\hline & \multirow[t]{2}{*}{ Senior staff } & 7 & 7 & 22 & 9 & 8 & 53 \\
\hline & & $50.0 \%$ & $30.4 \%$ & $52.4 \%$ & $47.4 \%$ & $61.5 \%$ & $47.7 \%$ \\
\hline \multirow{4}{*}{$\begin{array}{l}\text { Practice } \\
\text { (domestic) }\end{array}$} & \multirow[t]{2}{*}{ Yes } & 9 & 12 & 11 & 6 & 9 & 47 \\
\hline & & $64.3 \%$ & $52.2 \%$ & $26.2 \%$ & $31.6 \%$ & $69.2 \%$ & $42.3 \%$ \\
\hline & \multirow[t]{2}{*}{ No } & 5 & 11 & 31 & 13 & 4 & 64 \\
\hline & & $35.7 \%$ & $47.8 \%$ & $73.8 \%$ & $68.4 \%$ & $30.8 \%$ & $57.7 \%$ \\
\hline \multirow{4}{*}{$\begin{array}{l}\text { Degree in } \\
\text { other disci- } \\
\text { pline }\end{array}$} & \multirow[t]{2}{*}{ Yes } & 2 & 4 & 11 & 6 & 1 & 24 \\
\hline & & $14.3 \%$ & $17.4 \%$ & $26.2 \%$ & $31.6 \%$ & $7.7 \%$ & $21.6 \%$ \\
\hline & \multirow[t]{2}{*}{ No } & 12 & 19 & 31 & 13 & 12 & 87 \\
\hline & & $85.7 \%$ & $82.6 \%$ & $73.8 \%$ & $68.4 \%$ & $92.3 \%$ & $78.4 \%$ \\
\hline \multirow[t]{4}{*}{$\mathrm{PhD}$ in law } & \multirow[t]{2}{*}{ Yes } & 9 & 13 & 27 & 13 & 11 & 73 \\
\hline & & $64.3 \%$ & $56.5 \%$ & $64.3 \%$ & $68.4 \%$ & $84.6 \%$ & $65.8 \%$ \\
\hline & \multirow[t]{2}{*}{ No } & 5 & 10 & 15 & 6 & 2 & 38 \\
\hline & & $35.7 \%$ & $43.5 \%$ & $35.7 \%$ & $31.6 \%$ & $15.4 \%$ & $34.2 \%$ \\
\hline \multirow[t]{3}{*}{ Type } & \multirow[t]{2}{*}{ Private law } & 8 & 10 & 12 & 8 & 4 & 42 \\
\hline & & $57.1 \%$ & $43.5 \%$ & $28.6 \%$ & $42.1 \%$ & $30.8 \%$ & $37.8 \%$ \\
\hline & Public law & 5 & 12 & 20 & 6 & 5 & 48 \\
\hline
\end{tabular}

${ }^{80}$ See 2 b, above and Appendix 2, below. Although some of this information could have been gathered from university websites, we could not be certain that the websites were up to date, and important data was either unavailable (e.g. age) or incomplete (e.g. all qualifications). 


\begin{tabular}{|l|l|r|r|r|r|r|r|}
\cline { 2 - 7 } & & $35.7 \%$ & $52.2 \%$ & $47.6 \%$ & $31.6 \%$ & $38.5 \%$ & $43.2 \%$ \\
\cline { 2 - 8 } & \multirow{3}{*}{ Mixed } & 1 & 1 & 10 & 5 & 4 & 21 \\
\cline { 2 - 8 } & $7.1 \%$ & $4.3 \%$ & $23.8 \%$ & $26.3 \%$ & $30.8 \%$ & $18.9 \%$ \\
\hline \multirow{3}{*}{ Jurisdiction } & \multirow{2}{*}{ Domestic law } & 6 & 17 & 6 & 6 & 6 & 41 \\
\cline { 2 - 8 } & $42.9 \%$ & $73.9 \%$ & $14.3 \%$ & $31.6 \%$ & $46.2 \%$ & $36.9 \%$ \\
\cline { 2 - 8 } & Int'l, European or & 4 & 1 & 19 & 6 & 4 & 34 \\
\cline { 2 - 8 } & comparative law & $28.6 \%$ & $4.3 \%$ & $45.2 \%$ & $31.6 \%$ & $30.8 \%$ & $30.6 \%$ \\
\cline { 2 - 8 } & Mixed & 4 & 5 & 17 & 7 & 3 & 36 \\
\cline { 2 - 8 } & $28.6 \%$ & $21.7 \%$ & $40.5 \%$ & $36.8 \%$ & $23.1 \%$ & $32.4 \%$ \\
\hline
\end{tabular}

This table shows some interesting differences. For example, the fact that there are relatively few female legal scholars in the two German law schools may reflect the fact that in Germany, until around ten years ago, men were considerably more likely to study law than women. ${ }^{81}$ Given the different structure of universities, ${ }^{82}$ the two German law schools also have more young staff members than the three other law schools. In terms of qualifications, it is notable that in the two U.K. law schools relatively few staff members have a qualification to practice law, possibly reflecting the impact of the research assessment exercises, ${ }^{83}$ and that in Dublin relatively few staff members have a degree in another discipline but more than in the other law schools a $\mathrm{PhD}$ in law (pointing, with due caution because of the response rate, to a shift towards an academic approach but not to the wider interdisciplinary changes visible in the neighboring jurisdictions). With respect to the United Kingdom, it may be noted that almost all of the younger scholars tend to have a $\mathrm{PhD}$ (or are about to complete it), whereas some of the senior scholars entered legal academia at a time when it was still common to pursue a career in legal scholarship without a $\mathrm{PhD} .{ }^{84}$

In terms of subject matter specialization, it can be seen that in the two German law schools almost all of the respondents clearly indicated that they belong to either private or public law whereas in the three British and Irish law schools, mixtures are more common. The likely explanation is that in the common law world the divide between public and private law is of more recent origin. ${ }^{85}$ Finally, there are some interesting differences in terms of domestic or international law focus. The two U.K. universities have the lowest number of "pure" domestic scholars which is the likely to be the result of a relatively open international market for academic appointments. ${ }^{86}$ Edinburgh in particu-

\footnotetext{
${ }^{81}$ See data on law graduates, available at https://www.uni-due.de/isa/fg_wirtschaft_recht/rechtswiss/rechtswiss mw frm.htm.

${ }^{82}$ See Academic career maps in Europe, at http://www.leru.org/index.php/public/extra/careermapseurope.

${ }^{83}$ See 3 d (ii), above. See also Patricia Leighton, Tony Mortimer and Nicola Whatley, Today's Law Teachers: Lawyers or Academics? (London: Cavendish, 1995), 19-20 (large-scale study carried out by Anglia Polytechnic University in 1995 found that fewer than half of all law teachers, including university degrees and professional courses, in the United Kingdom had significant experience of legal practice).

${ }^{84}$ For the past situation see, e.g., Becher, supra note 23, at 108 (in the early 1980s in one of the leading law faculties only 5 out of $32 \mathrm{PhD}$ graduates).

${ }^{85}$ See, e.g., Mathias Siems, Comparative Law (Cambridge: Cambridge University Press 2014), 49.

${ }^{86}$ See Chistopher McCrudden, "A Comment on the Use of Foreign Professors in the German Council of Science and Humanities Report” (20 February 2014), available at http://www.verfassungsblog.de/en/acomment-on-the-use-of-foreign-professors-in-the-german-council-of-science-and-humanities-reportprospects-of-legal-scholarship-in-germany-current-situation-analyses-recommendations/.
} 
lar contains few "pure" domestic scholars which may also reflect the strong interest in comparative approaches in a small legal system sometimes considered as a mixture between common and civil law. ${ }^{87}$ By contrast, Düsseldorf has a strong focus on domestic law, possibly reflecting the importance of the centralized final exam which mainly focuses on domestic law, ${ }^{88}$

The following presents the arithmetic means of the three research methods, distinguished by those variables. It would also be possible to display the "centres" but, as we have seen previously, in our case, this leads to similar results. ${ }^{89}$

\section{(i) Personal characteristics}

Figure 3: Research preferences per gender, age and rank

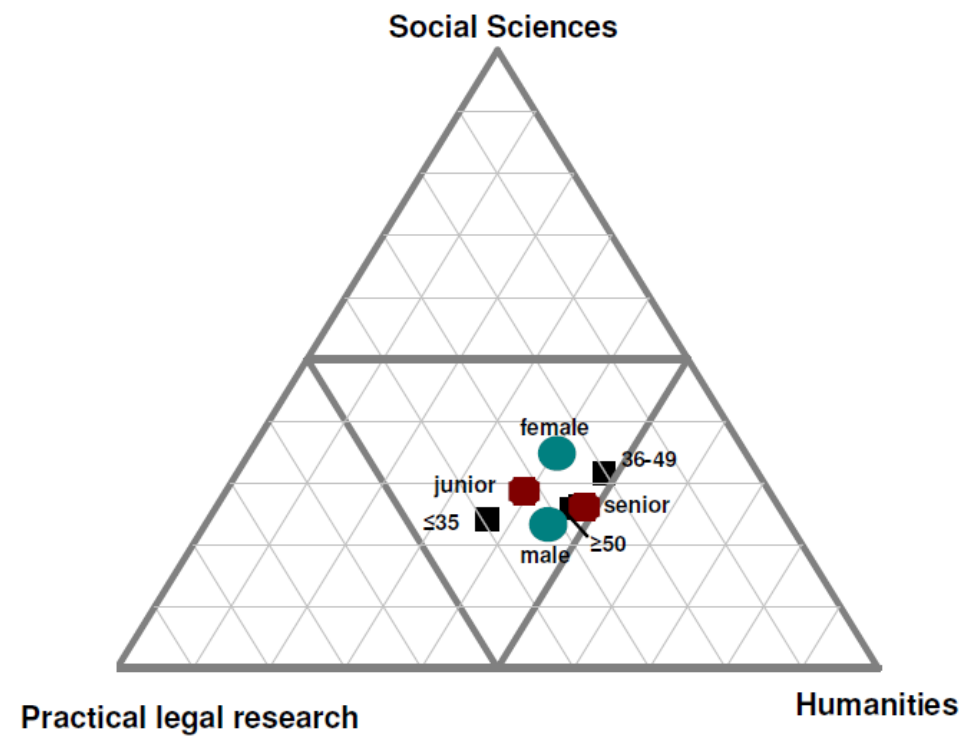

The ternary plot in Figure 3 shows that, in average, female scholars are closer to the social sciences than male scholars, whereas male scholars are closers to the other two categories. What may explain this gender difference? It may matter that, in the past, "law" has been a discipline where a clear majority of scholars were men. ${ }^{90}$ Thus, women who join law schools may felt the need to find a "niche" since it may have been difficult to get into the existing male networks of traditional doctrinal scholars, i.e. those predominantly associated with practical legal scholarship and law as humanities. ${ }^{91}$

In terms of age and rank, it is most interesting to see that younger and early-career scholars tend to be more "practical". This may be counterintuitive given evidence from the United States that new fields, such as "law and" scholarship, are preferred by

\footnotetext{
${ }^{87}$ See 3 d (i), above.

${ }^{88}$ See 3 c, above.

${ }^{89}$ See 3 b, above.

${ }^{90}$ See, e.g., for the United Kingdom, Cownie, supra note 10, at 168-75; Clare McGlynn, The Woman Lawyer: Making the Difference (London: Butterworths, 1998). For Germany see note 80, above.

${ }^{91}$ For the trend towards law as a social science, see also b (ii), below.
} 
younger academics. ${ }^{92}$ Yet, in our case, it may reflect that younger scholars received their legal training recently and that this is usually of a black-letter nature in the United Kingdom, Ireland and Germany. Thus, legal scholars may only adopt a more interdisciplinary perspective later on in their academic career. This can also be seen in some of the comments we received in our survey. Those included the lack of formal training in social science and how this inhibits the use of such methods (respondents from Scotland and Germany) $)^{93}$, even though "there might be occasions where it might be helpful" (respondent from Ireland). ${ }^{94}$ Several respondents indicated how the influence of interdisciplinary collaboration, for example in a research centre, has accounted for a later shift towards social sciences. ${ }^{95}$ A respondent from Germany also explained that classical methods tend to become less exciting as you progress with your research, and, similarly, one from England indicated that he "increasingly found 'pure' doctrinal law a little dull - and limiting in so far as there is a finite stock of material, albeit changing over time". 96

The fact that Figure 3 shows differences between junior and senior academics may, in the words of Tony Becher, show the "familiar contest of the Young Turks against the Old Guard". ${ }^{97}$ Here, then, the senior academics may be in a stronger position, as discussed in Pierre Bourdieu's study dealing with the "power and prestige" in the "academic field" in France. In particular, Bourdieu uses the notion of "academic capital" being "obtained and maintained by holding a position enabling domination of other positions and their holders", which he also links to age. ${ }^{98}$

In the present context, however, it also needs to be considered that the differences between the categories in the ternary plot may be regarded as relatively small, and that the age group of 50 or older is positioned between the other two groups. In addition, the ternary plot just indicated the mean, not the spread of the data. To identify the latter, it is possible to calculate the confidence intervals of the categories. ${ }^{99}$

\footnotetext{
92 William Landes and Richard Posner, "Heavily Cited Articles in Law", 71 Chicago-Kent Law Review 825, 836 (1996).

${ }^{93}$ Respondents EDI 15, EDI 21, BUC 9.

${ }^{94}$ Respondent TCD 2.

${ }^{95}$ Respondents HHU 4, EDI 9, UEA 12.

${ }^{96}$ Respondents BUC 13, UEA 18

${ }^{97}$ Becher, supra note 23 , at 72 .

${ }^{98}$ Bourdieu, supra note 10 , at 84,87 . See also Becher, supra note 23, at 58 (with the heading "Great men, gatekeepers and the exercise of power").

${ }^{99}$ This uses a function provided by CoDaPack (see $3 \mathrm{~b}$, above).
} 
Figure 4: 90\% and $95 \%$ centre confidence intervals for age differences

(a) Original data

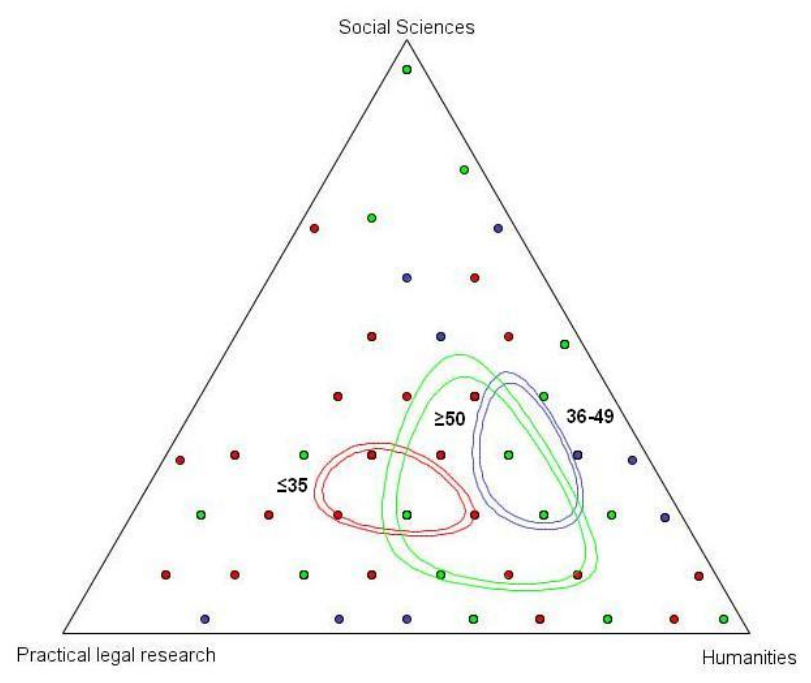

(b) Transformed data

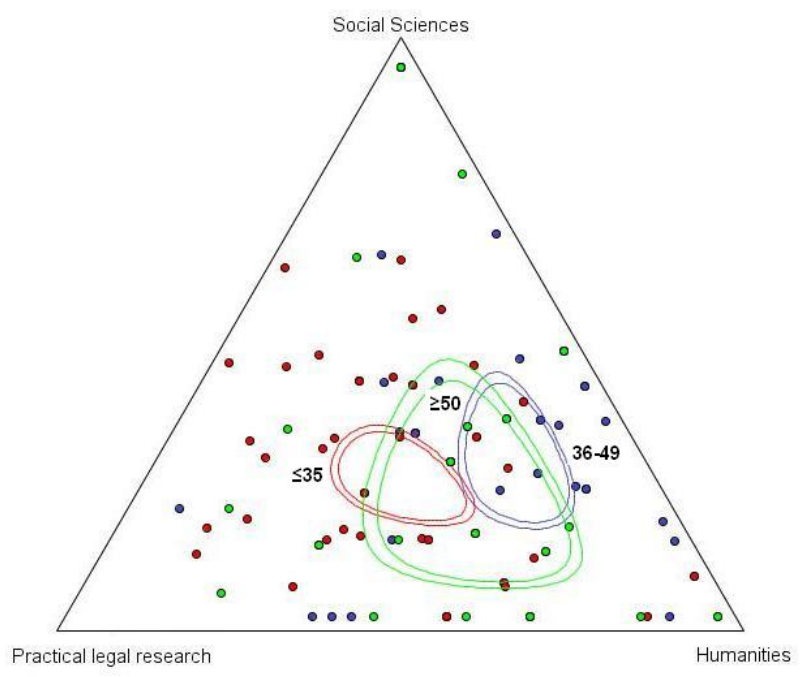

Figure 4 (a) shows that two of the circles do not overlap. Thus, we may say that we are $95 \%$ confident about the difference between the age groups $\leq 35$ and 36-49 years, while we cannot be sure about the difference between $\geq 50$ and the other two age groups. A problem with this result may be that the difference between the age groups could be driven by the differences between law schools: for example, we have received relatively many responses from young German legal scholars and German law schools tend to be more "practical", i.e. this could actually account for the age effect. The same could be the case for gender since we received relatively many responses from male German scholars, and the two German law schools also tend to be more practical.

Yet, further analysis does not confirm this suspicion. Checking the precise differences between the five law schools, there are similar age and gender effects in all but one of them (Dublin, where as already stated the response rate is low). Moreover, it is possible to conduct a more structured calculation, controlling for differences between law schools. For this purpose, we scaled the responses of each respondent according to the average of his/her university as compared to the overall average. Then, these transformed data can also be used to produce a ternary plot with centre confidence intervals. With respect to age, it can be seen that the Figure 4 (b) looks similar to the original data, for example, younger scholars have indeed a tendency to be more practical, and we can say with $90 \%$ confidence that there is a difference between the $\leq 35$ and 36-49 age groups. With respect to the other variables of this section - as well as the two subsequent ones - the group differences of the original data also show up if we use the transformed data. Thus, we can assume that differences between the law schools do not drive the results of our determinants, and in the following sections we will only report the unaltered data.

We did not find that the centre confidence intervals of the other variables, both of this section and the two subsequent ones, were significant at the $90 \%$ level: for example, the gender difference is only significant at the $70 \%$ level for the original and at the $65 \%$ level for the transformed data. This should not be a surprise given that often we only have a relatively low number of observations: for example, the age group $\geq 50$ are just 
22 respondents. It means that the findings of this section need to be interpreted with caution. For this reason we also provide frequent references to qualitative information (free text comments) in this section.

\section{(ii) Education and training}

Figure 5: Research preferences per qualifications

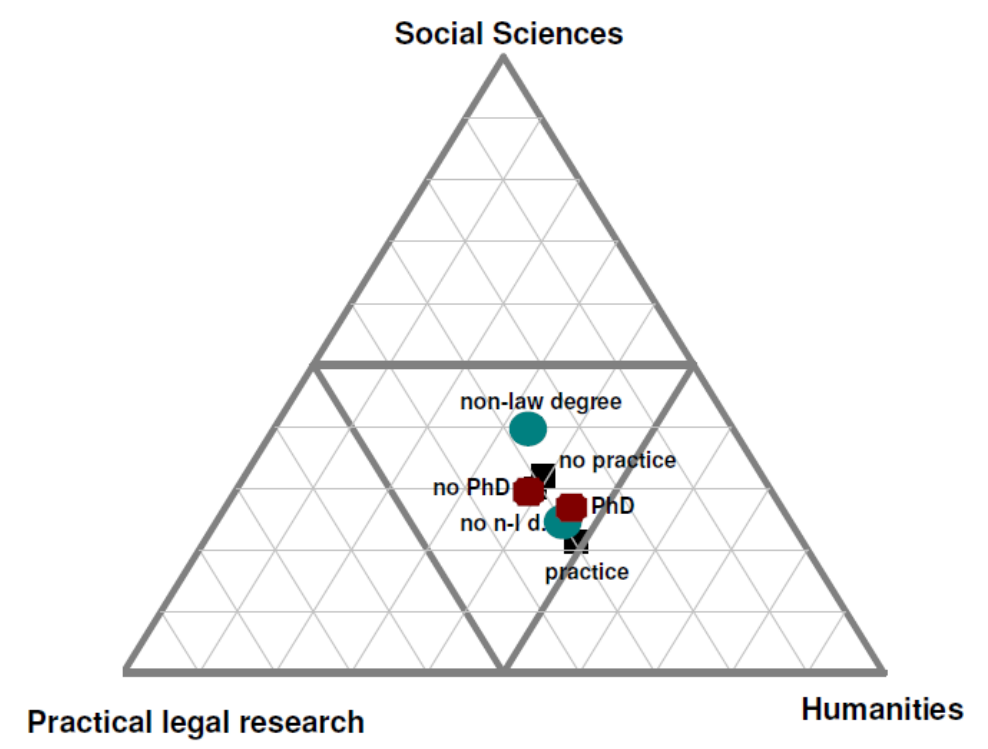

In their comments, many of our respondents indicated that training is a key facilitator of, and lack of training an important barrier to, methodological evolution. ${ }^{100}$ In particular, this is relevant for the social science methods - lest, legal scholars who want to engage in these methods just become "amateur social scientists". ${ }^{101}$ The quantitative data of Figure 5 confirm this observation for the aggregate level. It can also be checked that in all five law schools respondents with a non-law degree are more likely to associate with the view of law as a social science. In this respect, it is also notable that 17 of these 24 respondents have a non-law degree which can be classified as being part of the social sciences - mainly, business, sociology or criminology ${ }^{102}$ - while five have degrees from the humanities and two from the natural sciences.

Scholars who were formerly or continue to be legal practitioners are subject to a complex range of influences. While it might be assumed that such a scholar would have extensive knowledge of the interpretation methods that practitioners apply, and that these competences would have been highlighted and emphasized in their appointment by a university, it is not necessarily the case that a scholar of this nature would continue to focus on this method. Indeed, Figure 5 does not show that legal scholars who have a domestic qualification to practice law are more inclined to practical legal research than those who do not have such a qualification. In the free comments, respondents who had

\footnotetext{
${ }^{100}$ Respondents EDI 39, UEA 2; cf. respondents EDI 15, EDI 21, TCD 9

${ }^{101}$ Cf. also van Gestel et al., supra note 3, at 14.

102 This is line with Mathias Siems, "How close is 'law' to other academic disciplines?", available at http://siemslegal.blogspot.co.uk/2012/06/how-close-is-law-to-other-academic.html (examining the interdisciplinary papers of legal scholars in the U.K.'s Research Assessment Exercise 2008).
} 
formerly practiced law also often explained how this change in professional status was reflected, over time, in a move towards methods other than practical. For example, three comments from English and Scottish legal scholars argued that the need to substantiate a practical perspective through theory prompted a gradual move from practical towards humanities or pointed to new perspectives gained after leaving practice, although past experience of practice also encouraged research that analyzed this sector. ${ }^{103}$

A related question is whether a $\mathrm{PhD}$ in law makes a difference. In the U.K. context, it has recently been suggested that "in the mid-1990s, the rise of the $\mathrm{PhD}$ as an entry-level qualification changed the nature of some, even very traditional, law schools". ${ }^{104}$ Yet, Figure 5 does not show such impact on the preferred type of research. Here too, therefore, the plausible explanation is that legal scholars who do not have a $\mathrm{PhD}$ immerse themselves into the academic environment, not least since research of high quality (e.g. submitted for the REF) ${ }^{105}$ helps them in their academic career (in terms of promotion, research grants etc).

\section{(iii) Subject matter of research}

Figure 6: Research preferences per area of law and jurisdiction

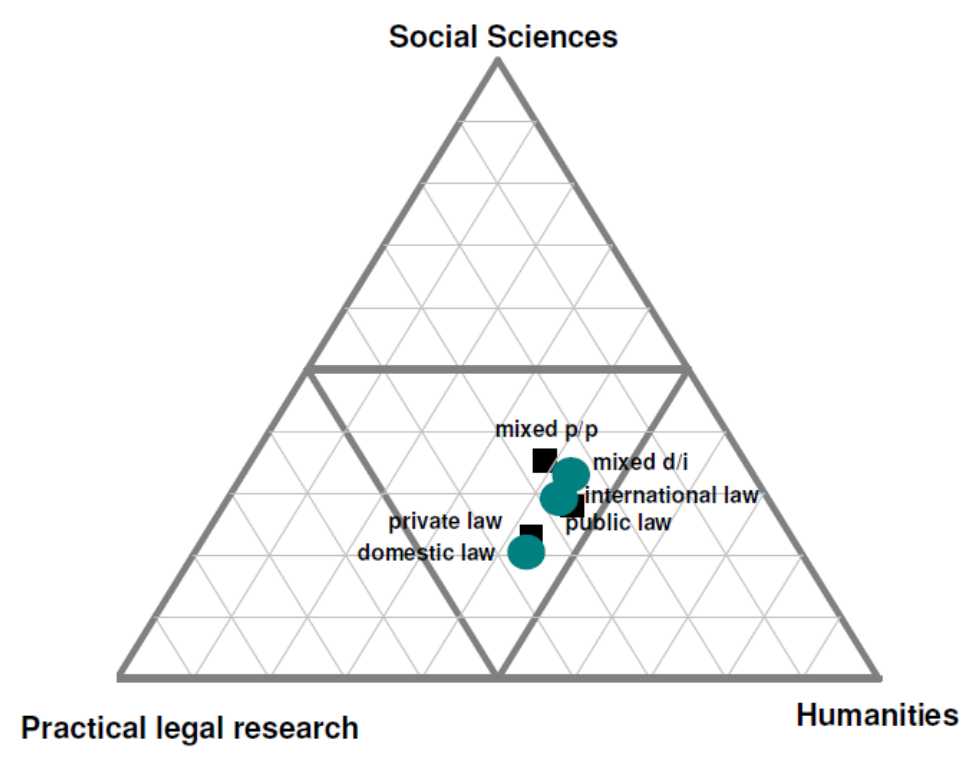

It may be expected that there is a relationship between working in a given area of law and the use of a method. ${ }^{106}$ Both our quantitative and qualitative data tend to confirm a number of possible differences. ${ }^{107}$ In our survey, we distinguished between public law

\footnotetext{
${ }^{103}$ Respondents EDI 2, UEA 11, UEA 13.

${ }^{104}$ SLSA discussion, 64 Socio-Legal Newsletter 4, 5 (2011) (quoting Sally Wheeler).

105 See 3 d (ii), above.

${ }^{106}$ For instance, Becher, supra note 23, at 133, makes the claim that jurisprudence is "pure" and family law is "nothing if not applied", although this may not reflect the methodological pluralism of present-day legal research.

107 The following quantitative observations hold for four of the law schools, not Dublin; but note that for the latter law school we only have a small number of observations in the three areas-of-law categories (4, 5, and 4 observations); thus, this non-result for Dublin should not be overinterpreted.
} 
(including criminal law), private law and mixtures between public and private law. Figure 6 shows that, on average, private lawyers are closer to practical legal research than public lawyers. This may reflect that the core areas of private law - contract, tort and property law - can be studied in a relatively apolitical way (i.e. accepting the common (private) law as a fair, efficient system rather than interrogating its underlying political basis) and can therefore be subject to a relatively positivist understanding. ${ }^{108}$ By contrast, there is a more "natural" links between research in public law and other disciplines (e.g., political science for constitutional law, economics for competition law and sectoral regulation). The relatively high social science affiliation of scholars who mix public and private law is also plausible since a scholar adopting a social science approach may often be interested in the way a particular aim is achieved, be it with tools of public or private law, rather than primarily interested in the doctrinal features of, for example, contract law.

Comments provided by our respondents on their areas of interest point to a similar direction. For example, one of them mentioned that his research on "property law theory" is bound to be "very much humanities-like". ${ }^{109}$ Another respondent indicated that in researching the law of protest, most other research came from non-legal disciplines, such as sociology and political science. ${ }^{110}$

The second distinction is between domestic law, international law (including comparative and European law) and mixtures between them. In the literature, Geoffrey Samuel suggests that comparative legal thinking challenges the "authority paradigm", and by doing so turns it into a social science. ${ }^{111}$ Two comments in our survey also indicate that "comparative law requires an interdisciplinary approach" and that "international law/EU law [is] considerably determined by political/economic context". ${ }^{112}$ Likewise, the quantitative data of Figure 6 show that legal scholars who mainly do domestic law are more likely to be associated with practical legal research.

A related question is whether, across law schools and countries, scholars engaged in international law (including comparative and European law) may gradually adopt a parallel approach to legal research. We therefore also calculated the mean scores per university - distinguishing those from pure domestic legal scholars. ${ }^{113}$

\footnotetext{
108 This may be different in areas of private business law (such as company law) where there could be closer links to disciplines such as economics and business studies. See also Adler and Simon, supra note 62, at 180-1 (on approaches to private law by scholars using different methods).

109 Respondent UEA 19.

${ }^{110}$ Respondent UEA 3.

${ }^{111}$ Geoffrey Samuel, "Is Law Really a Social Science? A View from Comparative Law”, 67 Cambridge Law Journal 288 (2008).

112 Respondent EDI 2.

113 Thus, here we combined the numbers for "international" and "mixed domestic / international" since "just international" has low n's for some of the universities (see Table 3, above: only 1 for Düsseldorf and only 4 for Bucerius and Dublin).
} 
Table 4: Mean scores for international and "mixed" legal scholars (and how they differ from those of pure domestic legal scholars)

\begin{tabular}{|l|c|c|c|}
\hline & Humanities & Social sciences & $\begin{array}{c}\text { Practical legal } \\
\text { research }\end{array}$ \\
\hline Bucerius (n: 8) & $3.00(-0.33)$ & $2.38(+1.04)$ & $4.63(-0.71)$ \\
\hline Düsseldorf (n: 6) & $3.67(-0.45)$ & $2.17(+0.34)$ & $4.17(+0.11)$ \\
\hline Edinburgh (n: 36) & $4.64(-1.53)$ & $3.33(+0.33)$ & $2.03(+1.19)$ \\
\hline UEA (n: 13) & $3.85(-0.32)$ & $3.85(+1.35)$ & $2.31(-1.03)$ \\
\hline Dublin (n: 7) & $5.71(+1.38)$ & $2.43(+0.10)$ & $1.86(-1.48)$ \\
\hline All (n: 70) & $4.33(-0.01)$ & $3.13(+1.03)$ & $2.54(-1.02)$ \\
\hline
\end{tabular}

It can be seen that in all five law schools international legal scholars are more likely to use methods of social sciences. ${ }^{114}$ In return, they are less likely to associate with practical legal research. The main exception is Edinburgh, although it needs to be noted that, here, few respondents have no interest in international law (or comparative/European law) (see Table 3, above) and, on average, the international scholars from Edinburgh are still less likely to be associated with practical legal research than those in three of the four other law schools.

In terms of convergence, however, we do not observe a similar method for international legal scholars, for example, given the continuing differences in practical legal research between the two German and the three other law schools. ${ }^{115}$ This may be seen as a problem if we think that uniform application of international (and EU) law requires a similar approach across countries. ${ }^{116}$ Yet, some "global" trends may lead to further changes, as the following will explain.

\section{b) Dominant and shifting paradigms}

In higher education studies it is discussed to what extent an academic discipline needs to share a certain level of homogeneity. ${ }^{117}$ This goes back to Thomas Kuhn who suggested that paradigms characterize "coherent traditions of scientific research". ${ }^{118}$ While such coherence may indicate some stability, according to Kuhn, there can also be "paradigm shifts" challenging current assumptions. Coherent traditions and corresponding shifts in legal research may also be identified with our survey approach. Yet, here, we will also

\footnotetext{
${ }^{114}$ See also Gregory Shaffer and Tom Ginsburg, "The Empirical Turn in International Legal Scholarship", 106 American Journal of International Law 1 (2012).

115 This is also evident if one compares German and English-language textbooks on topics of international law, EU law and comparative law; e.g., the former ones tend to put a stronger emphasis on conceptual thinking, while the latter ones are more often structured as "cases and materials".

${ }^{116}$ See van Gestel and Micklitz, supra note 5, at 297.

${ }^{117}$ See, e.g., Paul Trowler, "Depicting and Researching Disciplines: Strong and Moderate Essentialist Approaches", 39 Studies in Higher Education 1720 (2014) (rejecting the view of "essential characteristics which are all necessarily present in every instance").

${ }^{118}$ Thomas S. Kuhn, The Structure of Scientific Revolutions (Chicago: University of Chicago Press 3rd ed. 1996).
} 
have to consider that law is a diverse field, ${ }^{119}$ in particular given the differences between countries and law schools.

(i) Legal scholars with a clear methodological preference

Figure 7: Frequency of a dominant paradigm

Bucerius Düsseldorf Edinburgh UEA Dublin

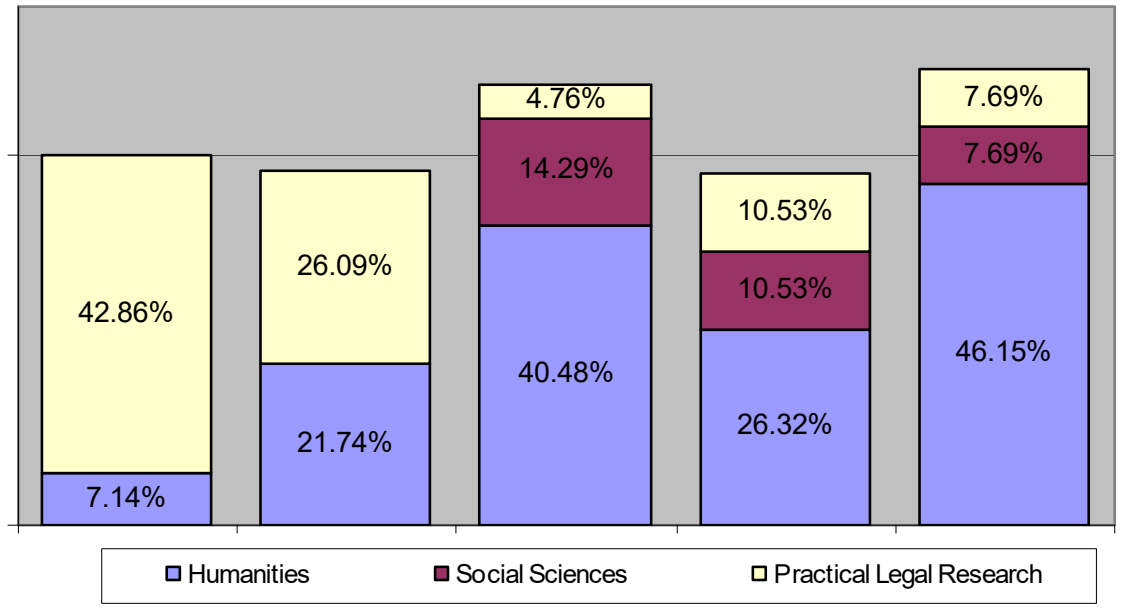

Figure 7 presents the research preferences of those respondents who have assigned a score of six or higher (out of ten) to one of the three categories. Thus, these legal scholars seem to have a dominant research paradigm. Figure 7 shows that this is the case for around $50 \%$ of the staff of each of the law schools, i.e. there is a roughly equal split between legal scholars who mix the three methods and those who predominantly use one of them.

In three institutions more than $40 \%$ of academics have the same dominant paradigm: humanities in Edinburgh and Dublin, and practical legal research at Bucerius. In such instances there may be some explicit or implicit pressure to follow this approach. The data also show that in the two German law schools practical legal research is the most frequent dominant method, whereas it is humanities in the three British and Irish law schools. Moreover, as noted previously, ${ }^{120}$ only the three latter universities have some academic staff who consider themselves as "full social scientists", for example, as they work as criminologists within a law school.

Overall, it can be seen that, at the levels of the law schools, there may be some support for a "core of legal research". ${ }^{121}$ Such a position may extend to lawyers in legal practice: Pierre Bourdieu writes about the "social cohesion" of scholars, "designed to ensure the durable homogeneity of the habitus". He then also mentions "law" as a discipline as requiring a high level of cohesion, given that "in the case of the jurists, a body

\footnotetext{
${ }^{119}$ Cf. Sanne Taekema and Bart van Klink, "Legal Methods under Discussion”, 1 Recht en Methode 1 (2011) ("In most sciences, generally accepted methods are the core of what constitutes the scientific discipline in question and what defines its scientific character. This is not the case for the discipline of law").

${ }^{120}$ See 3 c, above. See also 2 c, above, on the (possible) non-legal origins of "Law and Society".

${ }^{121}$ Cf. Susan Bartie, "The Lingering Core of Legal Scholarship”, 30 Legal Studies 345 (2010).
} 
of "authorities" cannot present itself in a state of disarray". ${ }^{122}$ Yet, this view of legal scholarship as supporting the need of legal practice may also have changed in recent years.

\section{(ii) Changes of research methods}

Figure 8: How did your methods change in the last ten years?

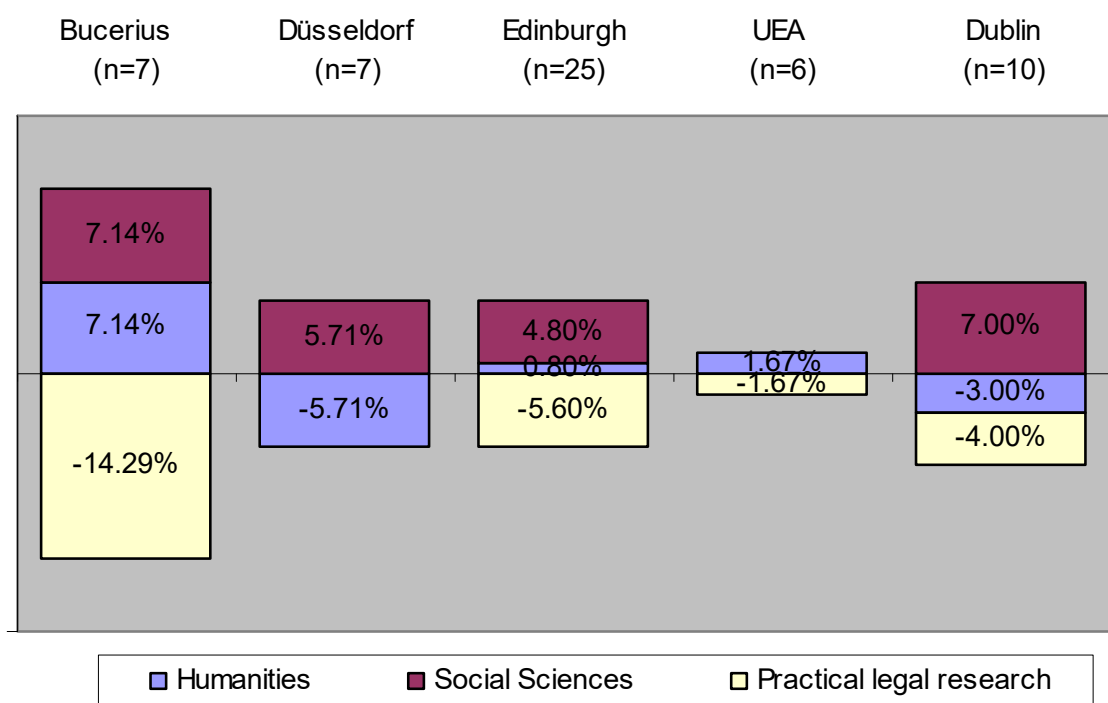

The respondents of our survey who were already academics ten years ago were also asked to indicate the methods they had used at that time. Figure 8 presents the result of these 55 respondents compared to the responses given by the same persons for their research preferences today. It can be seen that practical legal research has become less popular, and law as social sciences more popular, with a mixed development as regards law as humanities. This empirical finding shows a trend in line with our previous, more speculative, research about the developments in the United States, the United States and Germany. ${ }^{123}$

It is also possible to contextualize this trend within the wider debate about changes in legal research. Frequently the question is raised whether Europe should follow U.S. trends in legal scholarship and become less focused on doctrinal legal scholarship. ${ }^{124}$ Some even suggest that this is already reality. According to Mattias Kumm, there is a

"salutary effect of American elite law school culture on European scholarship. It has encouraged European scholars to overcome the residual habits of a conceptually focused positivist complacency and more widely reembrace the study of law as a theoretically ambitious, internally multidisciplinary exercise". ${ }^{125}$

\footnotetext{
122 Bourdieu, supra note 10 , at 65 .

${ }^{123}$ Siems and Mac Síthigh, supra note 2, at 671-4. Similar for the Netherlands (based on an empirical study) van Boom and van Gestel, supra note 43.

${ }^{124}$ Cf. van Gestel and Micklitz, supra note 5, at 292.

${ }^{125}$ Mattias Kumm, "On the Past and Future of European Constitutional Scholarship", 7 International Journal of Constitutional Law 401 (2009).
} 
More cautiously, it may be said that, in Europe, legal scholarship is now a discipline in transition. ${ }^{126}$ Of course, U.S. legal scholarship is also a moving target. ${ }^{127}$ In addition, the decline of doctrinal legal scholarship may not be a matter of course: Rob van Gestel and Hans-Wolfgang Micklitz note the possible counter-trend that the complex relationship between EU law and the law of the Member States requires "doctrinal scholarship with its focus on interpretation and systematisation". ${ }^{128}$

A good illustration of path-dependence and resistance is the discussion about a recent report by the German Wissenschaftsrat, a government-funded advisory body. ${ }^{129}$ In line with the German tradition, this report notes the character of law as a "professional discipline" (Professionsfakultät), seen as a discipline that is "closely linked to both the academic system and the respective societal system". The report also contains a modest support for more interdisciplinary legal scholarship at a subordinate level. ${ }^{130}$ Yet, even this modest suggestion is strongly criticized in a comment by a German professor who rejects any shift to "law and" research, arguing that this would "threaten what has made German legal science strong in the world: the dialogue between academia and judges, in particular the embedding of case law within legal doctrine". ${ }^{131}$

It is also clear that the way legal research traditions change is often a complex one. ${ }^{132}$ For example, while the individual researcher may follow a certain "herd behavior", 133 she is also able to find her own position within the academic field ${ }^{134}$ - or even to shape the way paradigms may persist or be subject to change. This leads us to the more general questions about the implications of our findings.

\footnotetext{
${ }^{126}$ See van Gestel and Micklitz, supra note 5, at 295 (on a recent Dutch research assessment exercise). See also Paul Chynoweth, "Legal Scholarship: A Discipline in Transition”, 1 International Journal of Law in the Built Environment 5 (2009); Cownie, supra note 10, at 54 (discipline in transition).

${ }^{127}$ See, e.g., Victoria Nourse and Gregory Shaffer, "Varieties of New Legal Realism: Can a New World Order Prompt a New Legal Theory", 95 Cornell Law Review 61 (2009) (on "new legal realism" and "cycles" with periods of more formalist and more socio-legal approaches); Adam Liptak, "The Lackluster Reviews That Lawyers Love To Hate" (New York Times 21 October 2013) available at http://www.nytimes.com/2013/10/22/us/law-scholarships-lackluster-reviews.html (discussing differences in peer review between law and other disciplines, and the impact of legal scholarship on judges and practitioners).

${ }^{128}$ van Gestel and Micklitz, supra note 5, at 294 (also ibid 310: revitalising doctrinal legal scholarship)

${ }^{129}$ English version available at http://www.wissenschaftsrat.de/download/archiv/2558-12 engl.pdf

${ }^{130}$ See Ralf Michaels, “'Law as the Study of Norms' - Foundational Subjects and Interdisciplinarity in Germany and the United States" (19 February 2014), available at http://www.verfassungsblog.de/de/lawas-the-study-of-norms-foundational-subjects-and-interdisciplinarity-in-germany-and-the-united-states/ (interpreting the report as suggesting a "subordinate role for interdisciplinarity").

${ }^{131}$ Christian Wolf, "Perspektiven der Rechtswissenschaft und der Juristenausbildung: Kritische Anmerkungen zu den Empfehlungen des Wissenschaftsrats", Zeitschrift für Rechtspolitik 20, 21 (2013) (own translation).

${ }^{132}$ Cf. Brian R. Cheffins, "The Trajectory of (Corporate Law) Scholarship", 63 Cambridge Law Journal 456, 458-77 (2004) (identifying five "trajectories for legal research").

${ }^{133}$ van Gestel and Micklitz, supra note 5, at 305-7; van Gestel et al, supra note 3, at 4.

${ }^{134}$ Cf. also Cownie, supra note 10, at 104-5 (autonomy as one of the advantages of academic life).
} 


\section{Implications of empirical findings}

It is often said that one cannot infer from "is" to "ought" statements. ${ }^{135}$ Thus, our empirical study cannot, and did not aim to, establish that one particular method of legal research is "better" than another one. ${ }^{136}$ Yet, it is possible to draw the following implications from our empirical findings.

\section{a) Thinking about methods of legal research}

The approach, underlying this paper, suggests that one way of understanding methods is through surveys of self-identification supplemented by an analysis of the respective institutions. Thus, in the words of Rob van Gestel and colleagues, this is seen as a way of "making the implicit explicit". ${ }^{137}$ We would suggest that the good response rate of our survey, as well as the observations made in the previous sections, also confirm the feasibility and value of such an approach, particularly when explicit consideration of methods is often absent from publications. But we also add a note of caution, from our experiences with carrying out the present project, that definitions and terms may not yet have a common understanding - and so, speaking the same language in a way that facilitates reasoned debate remains to be proven.

In substance, the fact that, according to our empirical findings, research methods in law differ considerably across countries can be considered as a major factor why we need to pay more attention to the method of legal research, especially if a more transnational discussion is intended. Given these differences, legal scholars may find that they cannot simply take the method, predominant in their jurisdiction, for granted. This is most evident for comparative lawyers, as a meaningful comparative study not only requires familiarity with differences in legal rules but also with those in legal style, mentality and method. Moreover, as legal systems become more and more interconnected due to international and European law but also soft factors - every legal scholar needs to have at least some familiarity with "foreign" understandings about the nature of legal scholarship. Awareness of these differences is particularly valuable for emerging scholars or potentially mobile researchers; recall that the mobility of academic researchers is a long-standing objective of EU projects and funding streams, as most recently restated in the Council Conclusions of 2012 on the European Research Area. ${ }^{138}$

Our empirical findings have shown that, in the law schools we studied, social science methods have become more and practical methods have become less popular in legal research. Growing interdisciplinarity suggests that legal scholars need to pay more ex-

\footnotetext{
135 The "is /ought problem" goes back to David Hume, A Treatise of Human Nature (London: J. Noon 1739), 335.

${ }^{136}$ See also Siems, supra note 16 (suggesting different ways of "being original" in legal research); Jan Vranken, "Exciting Times for Legal Scholarship", 2 Recht en Methode 42, 56 (2012) ("not to use the type of research as a quality indicator"); Ashish Kumar Singhal and Ikramuddin Malik, "Doctrinal and Sociolegal Methods of Research: Merits and Demerits", 2 Educational Research Journal 252, 256 (2012) ("no hierarchy amongst methodologies").

137 van Gestel and Micklitz, supra note 5, at 313; van Gestel et al, supra note 3, at 23. See also Smits, Mind and Method, above n 11, at 114-8 (on the merits and demerits of explicit research questions).

$138 \mathrm{http}$ ://www.consilium.europa.eu/uedocs/cms data/docs/pressdata/en/intm/134168.pdf paras 16-17 (11 December 2012). To be sure, this alone does not remove other institutional hurdles such as differences in research assessment procedures, see $3 \mathrm{~d}$ (ii), above.
} 
plicit attention to methodological questions. ${ }^{139}$ This is also in line with the finding of our survey as many of the respondents indicated that training (or lack of training!) is a key factor for the use of a particular method, and that understanding the diversity of methods facilitates other researchers in contextualizing published work and planning for collaborative efforts. ${ }^{140}$

Two further findings of this paper are that there is often a split between legal teaching and research, as well as a divergence between the research preferences of more senior and more junior legal scholars. ${ }^{141}$ It is suggested that greater awareness for the diversity of methods can reduce this split. In line with the practice in other academic disciplines, it would be plausible if legal education were to include more extensive training on diverse methodologies. This would then also be an advantage for more junior legal scholars as they would find it easier to choose and mix between different methods.

\section{b) Preferences for one or the other research methods}

This paper argues that in order to understand different research preferences, the sources of influences upon the adoption of methods by an individual scholar, and by groups or institutions, must be observed and understood. We point towards possible determinants of preferences, and consider (from a range of sources) why these preferences exist. Such an understanding of the range of influences is a part of the overall shift towards the placing of methodology at the centre of the legal academic discourse.

For about half of the respondents of our study these diverse sources of influence mean that they do not have a dominant method in terms of our three categories, but cluster in the "inner triangle" of the ternary plots. More specifically, we found that in the two U.K. law schools there is considerable variety in the methods that legal scholars use. This may indicate that law is a discipline in transition, possibly because today "we need more or other legal methods than in the past". ${ }^{142}$

In particular, it is interesting to observe different preferences in and changes to "practical legal research". According to our data, legal scholars that focus on domestic law tend to engage in such research more frequently than comparative and international legal scholars. Thus, given the increased interaction between legal systems (as well as interactions between economies, cultures, and societies), exclusive use of established, domestic legal methods can be seen as a barrier to the full realization of the potential of legal scholarship. As the audience for legal scholarship shifts, ${ }^{143}$ so may methodologies. For those interested in promoting humanities and social science approaches, this is also an opportunity to highlight the benefits such approaches could bring; training and events could be targeted at the "under-represented" group.

In four of the five law schools of our study academics answered that they use practical research methods less frequently than ten years ago. This may indicate a desire to

\footnotetext{
${ }^{139}$ See van Gestel et al, supra note 3 , at 8 .

140 See in particular 4 a (ii), above.

${ }^{141}$ See $3 d$ (ii) and 4 a (i), above.

142 van Gestel et al, supra note 3, at 7 .

${ }^{143}$ The question of the law school's relevant stakeholders has also been frequently discussed in the literature. See, e.g., Fiona Cownie (ed.), Stakeholders in Legal Education (Oxford: Hart Publishing 2009); Carel Stolker, Rethinking the Law School: Education, Research, Outreach and Governance (Cambridge: Cambridge University Press 2014), 290-324 ("Whose law school is it?"); Stefan PL de Jong et al., "Evaluation of Research in Context: An Approach and Two Cases", 20 Research Evaluation 61, 68 (2011).
} 
shift towards more interdisciplinary approaches in the "globalised world". However, despite this trend, we do not find a convergence in methods for legal scholars who, in our survey, indicate that they are engaged with research in international, European and/or comparative law. Thus, country differences are still more important for the choice of a particular method than the commonality of being an international scholar. This may be seen as a problem, for example, since EU law may be understood differently in the United Kingdom, Ireland and in Germany.

\section{c) Resistance and complementarities}

Parts of our empirical findings may be interpreted as verifying the existence of a dominant paradigm: at the country level, there are differences in particular between the two U.K. and the two German universities. In addition, at the level of individual scholars, we found the existence of a dominant model in respect of approximately half of the respondents. Both of these factors may prompt resistance against explicit legal methods which fall outside the "preferred" category. This can be seen in particular in the controversies about the use of tools of New Public Management in universities, such as the research assessment exercises in the United Kingdom. ${ }^{144}$

Criticism of our threefold categorization may also be some evidence of uncertainty in law schools on the approach to methods, with a related fear that categorization or identification is seen as a benchmark or a matter of "right" and "wrong". For instance, some respondents argued that there was no distinction or were not clear on the difference between practical legal research and law as humanities, while others were content with this definition and happy to apportion work between these categories. ${ }^{145}$

In substance, a plausible reason for resistance may be that any shift towards one particular method may weaken the previous one: for example, as research in law becomes more closely aligned to (other) social sciences, it may lose its attractiveness to legal practice. It was already mentioned that in Germany such a line of criticism has been directed against a recent report by the Wissenschaftsrat. ${ }^{146}$ In the United States there has also been a lively debate about the apparent rise of "impractical legal scholarship". ${ }^{147}$ Moreover, interdisciplinarity may - paradoxically - be criticized as reductionist far as it tells legal scholars to apply "ready-made categories and logics of [another] discipline". ${ }^{148}$

\footnotetext{
${ }^{144}$ See, e.g., Richard Rutter, "Margaret Thatcher Milk Snatcher: Higher Education and Universities", 12 April 2013, available at http://www.richierutter.com/margaret-thatcher-milk-snatcher-highereducationand-universities/; Claire Shaw, "Research that doesn't belong to single subject area is deemed 'too risky"" (Guardian Professional 21 November 2013), available at http://www.theguardian.com/higher-educationnetwork/blog/2013/nov/21/interdisciplinary-research-ref-submission-university.

${ }^{145}$ Respondents BUC 4, EDI 18, UEA 10; cf HHU 19. See also 2 c, above (explaining the categories).

${ }^{146}$ See 4 b (ii), above.

${ }^{147}$ E.g., Brent E. Newton, “Preaching What They Don't Practice: Why Law Faculties' Preoccupation with Impractical Scholarship and Devaluation of Practical Competencies Obstruct Reform in the Legal Academy", 62 South Carolina Law Review 105 (2010); Harry T. Edwards, "The Growing Disjunction between Legal Education and the Legal Profession", 91 Michigan Law Review 34 (1992). See also the recent discussion in blogs, e.g., http://balkin.blogspot.co.uk/2013/10/glass-houses-liptak-on-legal-scholarship.html and http://www.volokh.com/2011/07/23/chief-justice-roberts-and-current-legal-scholarship.

${ }^{148}$ Mariana Valverde, "Between a Rock and a Hard Place: Legal Studies Beyond Both Disciplinarity and Interdisciplinarity", 1 Critical Analysis of Law 51, 52 (2014) (in particular referring to economics). More
} 
Reflecting on differences between legal research in civil and common law countries, it may therefore be tempting to suggest that one should achieve the "best of all worlds" and mix the "legal science" approach of the former with the interdisciplinarity of the latter countries. ${ }^{149}$ Possibly, it could then be said that the two U.K. universities in our sample (in particular UEA) have already achieved such an equilibrium (including through staff turnover), given that all three categories carry some weight. ${ }^{150}$

However, it is not a matter of course that a mixed position is always the preferred one. The usefulness of such mixing may be limited by the "institutional complementarities" 151 of academic structures, such as those we considered in our previous work on this topic regarding university governance and external funding of research. ${ }^{152}$ This is not a new line of criticism. At a more philosophical level, Immanuel Kant noted that "every science is in itself a system" and that therefore we should not simply treat it as "part of another building" but "must work with it architectonically, as a building subsisting for itself". ${ }^{153}$ Thus, this may speak against any radical paradigm shifts in legal scholarship especially given the existence, in some shape or form, of links between university law schools and the regulated legal professions.

Beyond these general trends, we would suggest that thinking about the direction of law as an academic discipline must not lose sight of the freedom of choice of individual scholars. For example, as there are more basic and more advanced forms of interdisciplinary legal research, ${ }^{154}$ it should depend on one's own preferences and skills to what extent, say, a mere contextual legal analysis or a full-fledged empirical study is conducted. It is also clear - as it is reflected in some of findings of our survey - that the choice of methods is closely related to the subject matter a legal scholar aims to research. Thus, overall, there are good reasons to welcome the growing diversity of modern forms of legal research.

\section{Conclusion}

The "location" of academic disciplines is sometimes contentious: for example, while some medical researchers may consider themselves as part of the life sciences, others may emphasize the applied and practical nature of medical research. ${ }^{155}$ Another conten-

generally see also Jerry Jacobs, In Defense of Disciplines: Interdisciplinarity and Specialization in the Research University (Chicago: Chicago University Press, 2014).

${ }^{149}$ Markus D. Dubber, "New Legal Science: Toward Law as a Global Discipline” (2014), available at http://ssrn.com/abstract=2462224.

${ }^{150}$ See 3 b, above, as well as Figure 8, above (showing little change in preferences over time).

${ }^{151}$ For the general concept of "institutional complementarities" see Peter A Hall and David Soskice, Varieties of Capitalism: the institutional foundations of comparative advantage (Oxford: Oxford University Press, 2001), 17.

${ }^{152}$ See also Siems and Mac Síthigh, supra note 2, especially at 656-61 (faculties), 661-3 (research councils).

${ }^{153}$ Immanuel Kant, Kritik der Urteilskraft (1790), $\S 68$ as translated by J.H. Bernard, Kant's Critique of Judgement (London: Macmillan, 1914).

${ }^{154}$ See, e.g., Mathias Siems, “The Taxonomy of Interdisciplinary Legal Research: Finding the Way Out of the Desert", 7 Journal of Commonwealth Law and Legal Education 5 (2009).

155 See, e.g., Thomas H. Broman, The Transformation of German Academic Medicine, 1750-1820 (Cambridge: Cambridge University Press, 2002), 128; Robert E. Kohler, From Medical Chemistry to Biochemistry: The Making of a Biomedical Discipline (Cambridge: Cambridge University Press, 1982), ch. 6. See 
tious divide is between the social sciences and humanities: for example, in the United Kingdom, researchers in linguistics and media studies may either apply for funding to the research council for arts and humanities or the one for social sciences, depending on the specifics of their project. ${ }^{156}$

We suggest that legal scholarship is a field that is also torn between these dimensions of a practical discipline, the social sciences, and humanities. For the purposes of this paper, we conducted an empirical survey of five law schools across Germany, Ireland, and the United Kingdom. We asked legal scholars to indicate to what extent they use the methods of "legal research as part of humanities", of "legal research as part of social sciences", and/or of "legal research as akin to the analysis of law in legal practice". Subsequently, we presented our results with ternary plots and other tools of classical and compositional statistics. Some of the differences in results can be explained by specific features of the respective law schools. But there is also a clear country effect since scholars of the two German law schools have a relatively strong preference for practical legal research and scholars of the three U.K. and Irish law schools a relatively strong preference for law as humanities, with law as social sciences also being relatively strong in the two U.K. law schools. Our analysis suggests that these differences are largely driven by institutional differences in higher education.

In the survey we also collected information about possible determinants of research preferences at the individual level. We found that, for instance, international legal scholars (including EU and comparative lawyers) tend to be closer to the social sciences and that younger scholars and private lawyers tend to be closer to practical legal research. However, even within the group of international legal scholars there are the profound country differences indicated in the previous paragraph. Still, our data show some signs of convergence since, across the five law schools, legal scholars told us that they tend to use practical legal research methods less often, and social sciences methods more often, than ten years ago. In the implications of our empirical findings we elaborated on these and other trends. While our study did not aim to establish that one particular method of legal research is "better" than another one, we suggest that it shows that scholars need to pay attention to different methods, in particular the way these methods increasingly mix in order to achieve the "best of all worlds".

Future research could include content analysis of sample of papers and detailed interviews. This could enable researchers to identify differences between the (subjective) affinities or self-identification of scholars on one hand and the (objective) assessment of the use of methods by those same scholars. ${ }^{157} \mathrm{We}$ argue, however, that the views of the scholars we surveyed are deserving of consideration even without external review of their work as such self-identification may also have an aspirational dimension, thus, indicating possible future developments in legal scholarship.

also the analogies between law and medicine in Stolker, supra note 143, at 139; John Flood, "Doing Business: The Management of Uncertainty in Lawyers' Work”, 25 Law \& Society Review 41, 43-4 (1991).

${ }^{156}$ See http://www.ahrc.ac.uk/Funding-Opportunities/Research-funding/RFG/Additionalinformation/Pages/AHRC-and-ESRC-shared-interests.aspx.

${ }^{157}$ See also $2 \mathrm{~b}$, above. 


\section{Appendix 1: Email sent to legal scholars}

Survey on legal research methods

Dear [Name],

Mathias Siems and I are conducting a new study on research methods and it would be great if you could help us by responding to a few survey questions: it should not take more than three to five minutes!

We are studying legal research methods across a number of jurisdictions. The results will be presented at a workshop at the EUI in spring 2014 and subsequently published in a book, Methodology in the New Legal World.

Here is a link to the survey: [Link]

This link is uniquely tied to this survey and your email address. Please do not forward this message. Of course, the data will not be shared with anyone else - and in any subsequent publications we will only report the aggregate data per law school (and anonymise any free text comments).

This project is being carried out in accordance with the University of Edinburgh College of $\mathrm{Hu}-$ manities \& Social Science Code of Research Ethics. If you wish to withdraw from this project at any point after answering the survey, please contact us.

Many thanks!

Daithi and Mathias

Dr Daithi Mac Sithigh

Lecturer in Digital Media Law

Edinburgh Law School

University of Edinburgh

Old College, South Bridge

Edinburgh EH8 9YL

United Kingdom

http://www.law.ed.ac.uk/people/daithimacsithigh

Prof Mathias Siems

Professor of Commercial Law

Durham Law School

Durham University

Stockton Road

Durham DH1 3LE

United Kingdom http://www.dur.ac.uk/mathias.siems/
Umfrage zu juristischen Methoden

Sehr geehrter Herr / Sehr geehrte Frau [],

ich hoffe, dass ich Sie um einen kurzen Gefallen bitten dürfte. Herr Dr. Mac Sithigh und ich arbeiten an einem Projekt zum Einsatz juristischer Methoden und es wäre toll, wenn sie uns dabei kurz unterstützen könnten: es sollte nicht mehr als drei bis fünf Minuten dauern!

Wir untersuchen, welche Methoden Rechtswissenschaftler in verschiedenen Ländern verwenden. Die Ergebnisse werden im nächsten Jahr auf einer Konferenz am Europäischen Hochschulinstitut (EUI) vorgestellt und anschließend in einem Buch zu ,Methodology in the New Legal World" veröffentlicht.

Die Umfrage findet sich auf []

Dieser Internetlink bezieht sich speziell auf Ihre EmailAdresse. Bitte leiten Sie ihn deshalb nicht weiter. Selbstverständlich werden Ihre Daten strikt vertraulich behandelt - und in den nachfolgen Publikationen werden wir nur die Aggregatdaten für jede Fakultät wiedergeben (und die Kommentare im Freitextfeld anonymisieren).

Unser Projekt wird in Übereinstimmung mit dem Forschungskodex der Universität Edinburgh, UK, durchgeführt. Es ist Ihnen jederzeit gestattet, Ihre Beteiligung zurückzuziehen.

Vielen Dank und beste Grüße,

Mathias Siems und Daithi Mac Sithigh

Prof. Dr. Mathias Siems, LL.M.

Professor of Commercial Law

Durham Law School

Durham University

Stockton Road

Durham DH1 3LE

United Kingdom http://www.dur.ac.uk/mathias.siems/

Dr. Daithi Mac Sithigh

Lecturer in Digital Media Law

Edinburgh Law School

University of Edinburgh

Old College, South Bridge

Edinburgh EH8 9YL

United Kingdom

http://www.law.ed.ac.uk/people/daithimacsithigh 
Appendix 2: Questionnaire / survey

Part 1. Which method(s) do you use in your research?

Please assume that there are three main methods of legal research:

o Legal research as part of humanities, i.e. analysis of legal texts (cases, statutes etc) using approaches similar to research in humanities (history, philosophy, literature, theology, etc.)

o Legal research as part of social sciences, i.e. analysis of law in its context, similar to research in social sciences (sociology, economics, psychology etc).

o Legal research as akin to the analysis of law in legal practice, i.e. similar to the approaches used by legal practitioners (judges, solicitors etc.)

1) In your current research how frequently do you use one of these three approaches?

Please allocate in total 10 points (e.g., something like $5 / 5 / 0$ or $3 / 3 / 4$ ). Note that mixtures can be the result of a mix of these approaches in individual pieces or across various research outputs. Please also note that these categories refer to method not substance.

2) If you were engaged in legal research in the course of employment ten years ago (i.e. in autumn 2003), how frequently did you use one of these three approaches at that time? If you were not so engaged, please skip this question.
Teil 1: Welche Methoden verwenden Sie in Ihrer Forschung?

Bitte nehmen Sie an, dass die juristische Forschung in die folgenden drei Methoden untergliedert werden kann:

o Juristische Forschung als Teil der Geisteswissenschaft, d. h. Forschung, die juristische Texte (Gesetze, Gerichtsentscheidungen etc.) mit Methoden analysiert, die denen der Geisteswissenschaften (Geschichte, Philosophie, Literatur, Theologie etc.) entsprechen.

o Juristische Forschung als Teil der Sozialwissenschaften, d. h. Forschung, die das Recht im Kontext mit Methoden untersucht, die denen der Sozialwissenschaften (Soziologie, Ökonomie, Psychologie etc.) entsprechen.

o Juristische Forschung als ähnlich der juristischen Vorgehensweise der Rechtspraxis, d. h. Forschung, die das Recht mit Methoden analysiert, die denen von Rechtspraktikern (Richtern, Anwälten etc.) entsprechen.

1) Wie häufig verwenden sie diese Methoden in Ihrer gegenwärtigen Forschung?

Bitte verteilen Sie insgesamt 10 Punkte (z. B. so etwas wie $5 / 5 / 0$ oder $3 / 3 / 4$ ). Hinweis: Mischungen können sich daraus ergeben, dass Publikationen verschiede Methoden verknüpfen oder dass in verschiedenen Publikationen unterschiedliche Methoden verwendet werden. Bitte beachten sie auch, dass sich die drei Kategorien auf Methoden und nicht den Inhalt der Publikationen beziehen.

2) Wenn Sie bereits vor zehn Jahren (also im Herbst 2003) beruflich mit juristischer Forschung beschäftigt waren, wie häufig haben sie diese drei Methoden zu dieser Zeit verwendet. Falls dies nicht der Fall war, überspringen Sie bitte diese Frage. 
Part 2. Further questions

1) Gender: (a) male, (b) female

2) Age: (a) 35 or younger; (b) 36 to 49; (c) 50 or older

3) Current position - please choose one:

(a) Lecturer; (b) Senior Lecturer, Reader, Professor; for Germany: (a) Professor (W2, W3 or equivalent); (b) any other position

4) Form of employment - please choose one: (a) full-time; (b) part-time (if yes, please indicate percentage)

5) Main area of research - please choose one: (a) predominantly public law (including criminal law); (b) predominantly private law; (c) mixed. Note: "predominantly" means at least $60 \%$ (e.g., if you have a 55\% / 45\% split please choose (c))

6) Scope of your research - please choose one (a) predominantly concerned with UK and/or Scots law; (b) predominantly comparative, international and/or European; (c) mixed. Note: "predominantly" means at least $60 \%$ (e.g., if you have a 55\% / 45\% split please choose (c))

7) Training - please choose as many as applicable:

(a) undergraduate law degree or equivalent (e.g., State Exam in German, JD in the US): (i) domestic (with variation for Scotland/UK, (ii) overseas

(b) masters degree in law (or equivalent): (i) domestic and/or (ii) abroad

(c) doctoral degree in law: (i) domestic and/or (ii) abroad

(d) eligibility to practice law following professional legal qualification: (i) domestic and/or (ii) abroad

(e) degree other than law [free text: if yes, please specify level - undergraduate, master or doctorate and discipline]
Teil 2: Weitere Fragen

1) Geschlecht: männlich, weiblich

2) Alter: 35 oder jünger, 36 bis 49,50 oder älter

3) Gegenwärtige Position: Professor (W2, W3 oder entsprechend), sonstige Position

4) Art des Anstellungsverhältnisses: Vollzeit, Teilzeit (wenn ja, bitte geben Sie die Prozentzahl an)

5) Hauptforschungsgebiet - bitte wählen Sie eines: hauptsächlich Öffentliches Recht (inklusive Strafrecht); hauptsächlich Privatrecht; gemischt. Hinweis: „hauptsächlich“ ist definiert als mindestens $60 \%$ (wenn also z. B. die Aufteilung $55 \%$ / $45 \%$ ist, wählen Sie bitte (c)).

6) Umfang Ihrer Forschung - bitte wählen Sie eines: hauptsächlich deutsches Recht, hauptsächlich vergleichendes, internationales und/oder Europäisches Recht; gemischt. Hinweis: „hauptsächlich“ ist definiert als mindestens $60 \%$ (wenn also z. B. die Aufteilung $55 \%$ / $45 \%$ ist, wählen Sie bitte (c)).

7) Ausbildung - bitte wählen so viele wie zutreffend:

(a) Erstes juristischen (Staats-)examen oder Äquivalent (z. B. LLB oder JD) in Deutschland, im Ausland

(b) Juristischer Masterabschluss (z. B. LL.M.) in Deutschland und/oder im Ausland

(c) Juristische Promotion in Deutschland und/oder im Ausland

(d) Zweites juristisches Staatsexamen oder Äquivalent in Deutschland und/oder im Ausland

(e) Abschluss in einer anderen Fachrichtung (bitte geben Sie den genauen Abschluss - Grad und Disziplin - an) 


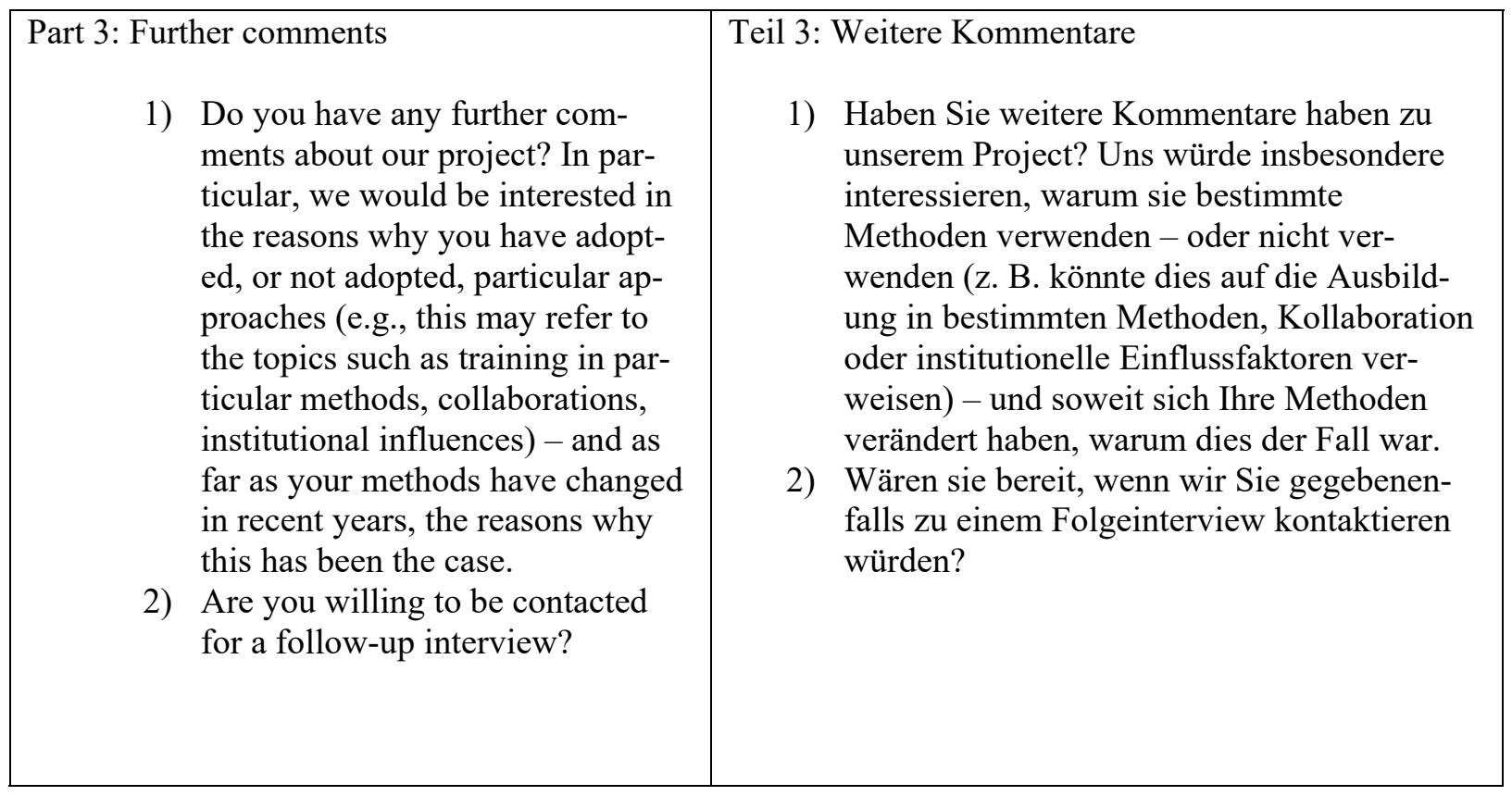

